\title{
Progressive Hearing Loss in Mice Carrying a Mutation in Usp53
}

\author{
Marcin Kazmierczak, ${ }^{1}$ Suzan L. Harris, ${ }^{1}$ Piotr Kazmierczak, ${ }^{2}$-Prahar Shah, ${ }^{1}$ Valentin Starovoytov, \\ Kevin K. Ohlemiller, ${ }^{3}$ and Martin Schwander ${ }^{1}$ \\ ${ }^{1}$ Department of Cell Biology and Neuroscience, Rutgers, The State University of New Jersey, Piscataway, New Jersey 08854, ${ }^{2}$ National Institute of Health and \\ Medical Research, Unit 1051, Institute for Neurosciences of Montpellier, F-34091 Montpellier, France, and ${ }^{3}$ Department of Otolaryngology-Head and Neck \\ Surgery, Washington University School of Medicine, St. Louis, Missouri 63110
}

Disordered protein ubiquitination has been linked to neurodegenerative disease, yet its role in inner ear homeostasis and hearing loss is essentially unknown. Here we show that progressive hearing loss in the ethylnitrosourea-generated mambo mouse line is caused by a mutation in Usp53, a member of the deubiquitinating enzyme family. USP53 contains a catalytically inactive ubiquitin-specific protease domain and is expressed in cochlear hair cells and a subset of supporting cells. Although hair cell differentiation is unaffected in mambo mice, outer hair cells degenerate rapidly after the first postnatal week. USP53 colocalizes and interacts with the tight junction scaffolding proteins TJP1 and TJP2 in polarized epithelial cells, suggesting that USP53 is part of the tight junction complex. The barrier properties of tight junctions of the stria vascularis appeared intact in a biotin tracer assay, but the endocochlear potential is reduced in adult mambo mice. Hair cell degeneration in mambo mice precedes endocochlear potential decline and is rescued in cochlear organotypic cultures in low potassium milieu, indicating that hair cell loss is triggered by extracellular factors. Remarkably, heterozygous mambo mice show increased susceptibility to noise injury at high frequencies. We conclude that USP53 is a novel tight junction-associated protein that is essential for the survival of auditory hair cells and normal hearing in mice, possibly by modulating the barrier properties and mechanical stability of tight junctions.

Key words: hearing loss; inner ear; mambo mice; tight junction; ubiquitin; Usp53

\section{Significance Statement}

Hereditary hearing loss is extremely prevalent in the human population, but many genes linked to hearing loss remain to be discovered. Forward genetics screens in mice have facilitated the identification of genes involved in sensory perception and provided valuable animal models for hearing loss in humans. This involves introducing random mutations in mice, screening the mice for hearing defects, and mapping the causative mutation. Here, we have identified a mutation in the Usp53 gene that causes progressive hearing loss in the mambo mouse line. We demonstrate that USP53 is a catalytically inactive deubiquitinating enzyme and a novel component of tight junctions that is necessary for sensory hair cell survival and inner ear homeostasis.

\section{Introduction}

Hair cells in the mammalian cochlea are highly specialized epithelial cells that convert sound-induced vibrations into electrical

\footnotetext{
Received May 21, 2015; revised Sept. 24, 2015; accepted 0ct. 14, 2015.

Author contributions: M.K., S.L.H., K.K.O., and M.S. designed research; M.K., S.L.H., P.K., P.S., V.S., K.K.O., and M.S. performed research; M.K., S.L.H., P.K., P.S., V.S., K.L.O., and M.S. analyzed data; M.K., P.K., and M.S. wrote the paper.

This work was supported in part by National Institute on Deafness and Other Communication Disorders (NICDC) Grant DC013331 (M.S.). The generation of the mambo mice and the identification of the affected gene was performed with funding from NIDCD Grant DC014713 and DC007704 to Ulrich Mueller (The Scripps Research Institute, La Jolla, (A). We thank Rajvi Shah and other members of the Schwander laboratory for helpful discussions, WeiXiong for technical assistance with injectoporation assays, and Bechara Kachar for providing us with expression constructs for occludin and claudins.

The authors declare no competing financial interests.

Correspondence should be addressed to Martin Schwander, Rutgers, The State University of New Jersey, 604
}

signals through $\mathrm{K}^{+}$-mediated depolarization (Fig. 1). The apical surface of hair cells is surrounded by the endolymph, a $\mathrm{K}^{+}$-rich extracellular fluid produced by the stria vascularis, whereas the basal end is surrounded by the low $\mathrm{K}^{+}$perilymph (Wangemann, 2006). Tight junctions (TJs) connect the apices of hair cells and supporting cells in the reticular lamina and separate the basal and apical surfaces of these cells, preventing paracellular leakage of solutes (Gulley and Reese, 1976). Likewise, TJ barriers in the stria vascularis maintain the endolymph at a high positive resting potential, the endocochlear potential (EP), which provides the driving force for hair cell transduction.

\footnotetext{
Allison Road, Piscataway, NJ 08854. E-mail: schwander@biology.rutgers.edu. DOl:10.1523/JNEUROSCI.1965-15.2015

Copyright $\odot 2015$ the authors $\quad 0270-6474 / 15 / 3515582-17 \$ 15.00 / 0$
} 

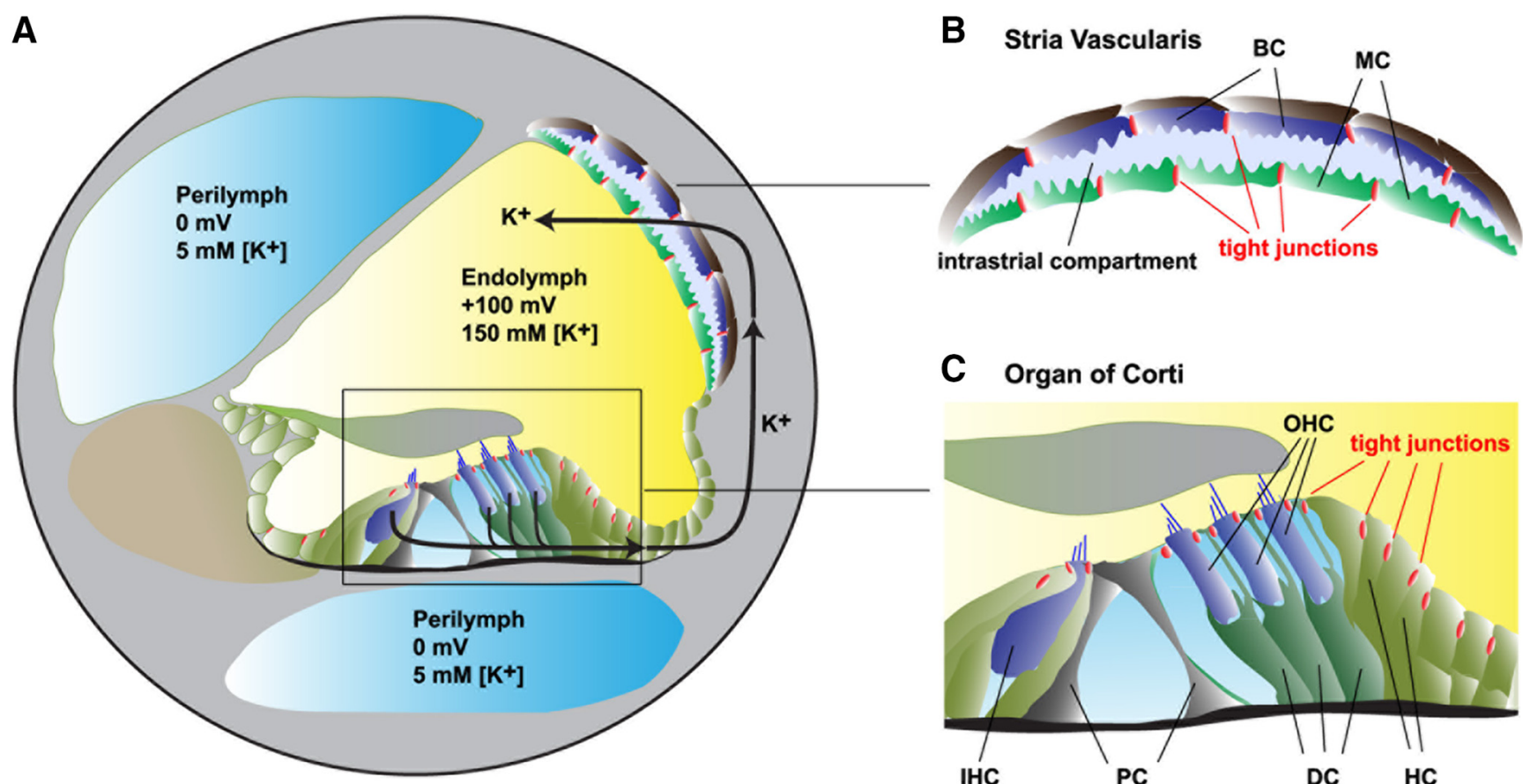

\section{Organ of Corti}

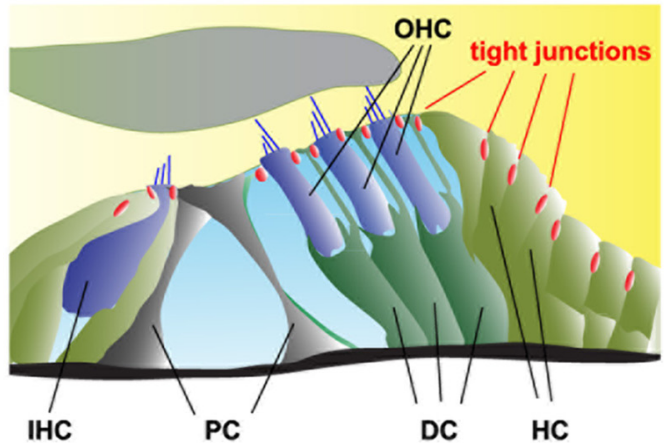

Figure 1. The role of Tss in cochlear ion homeostasis. $A$, Schematic diagram of a cochlear turn. TJs (red) in cochlear epithelial cells separate fluid-filled compartments of remarkably distinct ionic composition: $\mathrm{K}^{+}$-rich endolymph (yellow) and low $\mathrm{K}^{+}$perilymph (blue). $\mathrm{K}^{+}$enters stereocilia of hair cells during acoustic stimulation, exits at the hair cell base through $\mathrm{K}^{+}$channels in the basolateral membrane, and cycles back to the stria vascularis through a system of gap junctions in cochlear supporting cells (arrows). $\boldsymbol{B}$, TJs in basal and marginal cells of the stria vascularis preclude paracellular diffusion of molecules into and out of the intrastrial compartment. C, TJs in the reticular lamina of the organ of Corti prevent mixing of endolymph and perilymph. BC, Basal cells; $\mathrm{MC}$, marginal cells; IHC, inner hair cells; $\mathrm{OHC}$, outer hair cells; DC, Deiters' cells; PC, Pillar cells; HC, Hensen's cells.

TJs are composed of integral, peripheral membrane and intracellular proteins that form a network of sealing strands near the apical cell borders. Major integral membrane TJ proteins are the claudins and occludin that join the membranes of adjacent cells via trans-homophilic interactions while connecting intracellularly to the actin cytoskeleton through adaptor proteins, such as zonula occludens (ZO)-1/tight junction protein (TJP) 1, ZO-2/ TJP2, and ZO-3/TJP3 (Furuse et al., 1993; Steed et al., 2010; Tamura and Tsukita, 2014).

Disturbance of cochlear ion homeostasis attributable to impaired TJs is the cause of many forms of hearing loss. Mutations in CLDN14, encoding claudin-14, underlie human hereditary deafness DFNB29 (Wilcox et al., 2001). Claudin-11 null mice lack the EP and develop hearing loss as a result of defects in basal cell TJs of the stria vascularis (Gow et al., 2004; Kitajiri et al., 2004). In contrast, hearing loss in claudin-9, claudin-14, occludin, tricellulin, and ILDR1-deficient mice has been ascribed to altered leakiness of TJs in the organ of Corti and an increased concentration of $\mathrm{K}^{+}$around the basolateral surfaces of the outer hair cells (OHCs), resulting in hair cell degeneration (Ben-Yosef et al., 2003; Nakano et al., 2009; Nayak et al., 2013; Kitajiri et al., 2014; Morozko et al., 2015). Finally, genomic duplication and overexpression of TJP2 has been linked to nonsyndromic deafness DFNA51 (Walsh et al., 2010).

TJs are highly dynamic structures, and their barrier function is modulated by different signaling pathways and posttranslational protein modifications, including phosphorylation and palmitoylation (Antonetti et al., 1999; Van Itallie et al., 2005). The role of protein ubiquitination in this process is less well understood. Ubiquitination regulates protein stability, function, and/or localization and is critical for a multitude of cellular functions (Hershko and Ciechanover, 1998). Ubiquitin is conjugated to lysine residues in target proteins by E3 ubiquitin ligases either as a single unit (monoubiquitination) or as a branched chain (polyubiquitination) (Komander and Rape, 2012). In particular, lysine 48-linked polyubiquitin chains target proteins for proteasomal degradation. Protein ubiquitination is counter-regulated by deubiquitinating enzymes (DUBs), which cluster in five protein families: ubiquitin C-terminal hydrolases (UCHs), ubiquitin-specific proteases (USPs), ovarian tumour proteases (OTUs), Josephins, and JAB1/MPN/MOV34 metalloenzymes (JAMMs) (Komander et al., 2009). The USP family constitutes the largest family. Despite extensive studies on E3 ligases in inner ear homeostasis (Zenker et al., 2005; Nelson et al., 2007), the physiological role of USPs and other DUBs is poorly defined.

Here, we report the phenotypic characterization of a mutant Usp53 allele termed mambo, which was isolated from a forward genetics screen in mice. mambo mice carry a point mutation in the predicted catalytic domain of Usp53 and exhibit a rapidly progressive hearing loss. Usp53 is expressed broadly in the inner ear, and OHC survival is affected selectively in the cochlea. USP53 and the adaptor proteins TJP1 and TJP2 bind to each other and colocalize at TJs in epithelial cells, suggesting that they form a complex critical for TJ function. Remarkably, OHCs evade degeneration in organ culture, indicating that unfavorable extracellular conditions promote $\mathrm{OHC}$ degeneration in mambo mice. Together with previous studies, our findings support the idea that cochlear fluid homeostasis is tightly regulated by the actions of ubiquitin ligases and DUBs and suggest that molecular components of the ubiquitin pathway are potential risk factors for progressive hearing loss.

\section{Materials and Methods}

All procedures were performed in accordance with research guidelines of the institutional animal care and use committee of Rutgers University. Mice of either sex were studied. 
Ethylnitrosourea mutagenesis screen, auditory brainstem response, and distortion product otoacoustic emission measurement. The ethylnitrosourea (ENU) mutagenesis protocol and primary phenotypic screen has previously been described (Reijmers et al., 2006; Schwander et al., 2007). The measurement of auditory brainstem responses (ABRs), distortion product otoacoustic emissions (DPOAEs), as well as the assessment of vestibular function in open-field and swim tests followed our published procedures (Schwander et al., 2007).

Linkage analysis and DNA sequencing. Genome-wide single nucleotide polymorphism (SNP) genotyping for linkage analysis was performed as described previously (Schwander et al., 2007). Affected mambo mice were bred with BALB/cByJ mice. To identify the mambo mutation, a list of annotated and predicted genes in the affected interval was established using the University of California Santa Cruz (UCSC) genome browser. Total RNA was isolated from inner ear tissue of postnatal day 5 (P5) wild-type and mambo mice. cDNA was generated using oligo-dT primers and SuperScript II reverse transcriptase (Life Technologies). Annotated and predicted genes in the genomic interval were amplified using Phusion DNA polymerase (New England Biolabs) and sequenced with primers specific to the full-length gene. In addition, exon-based sequencing of candidate genes was performed with primers designed via the Exon Primer function in the UCSC Genome browser (http://genome.ucsc.edu/).

Mouse genotyping. Genotyping was performed by PCR using a set of primers that flank the mambo mutation in the Usp53 gene: forward primer 796f, 5' - CTTCAGATACACTTTGATTTTCATTG-3', and reverse primer 796r, 5' -GGTTCAGATGAACAAAACTAAGACC-3'. PCR fragments were purified and digested with TspRI for $4 \mathrm{~h}$ at $65^{\circ} \mathrm{C}$ to give a 310 bp product in wild-type mice, 110 and 200 bp products in homozygous mutants, and all three products in heterozygous littermates.

DNA constructs. The mouse Usp53 gene contains 16 exons, of which 15 are coding, distributed over $51 \mathrm{~kb}$ of genomic DNA. Several partial and two complete sequences of Usp53 transcripts have been described. A short transcript (GenBank AK045953.1) encodes a putative protein fragment with an incomplete $\mathrm{N}$-terminal catalytic domain (amino acids 1-274) and nine additional amino acids. The apparent full-length cDNA (NCBI Reference Sequence: NM_133857.3) encoding mouse USP53 (1069 aa) was amplified from cochlear RNA by RT-PCR and inserted in-frame into XhoI and SacII sites of pEGFP-C1 (Clontech). The mambo mutation (p.C228S) was introduced into USP53 by overlap PCR using $\mathrm{XhoI} / \mathrm{SacII}$ as flanking restriction sites. Mutation of the predicted Src homology 3 (SH3) binding domain (amino acids 1008-1013; PPPLPP to AAALAA) was performed by overlap PCR using SalI/SacII sites. The catalytic domain (amino acids 1-348) and the tail domain (amino acids 393-1069) of USP53 were amplified by PCR and subcloned into pEG$\mathrm{FP}-\mathrm{C} 1$ using XhoI/SacII sites. Additional C-terminal truncation mutants C1 (amino acids 1-1017), C2 (amino acids 1-900), and C3 (amino acids 1-676) were amplified by PCR and inserted in-frame into SalI/SacII (C1, C2) and KpnI/SacII (C3) sites of pEGFP-C1. Full-length human TJP2 in p2xFlag CMV2 was obtained from Addgene (plasmid 27415; Oka et al., 2010). All constructs were verified by DNA sequencing.

Histology, electron microscopy, and immunolocalization studies. Whole-mount staining, transmission electron microscopy (TEM), and scanning electron microscopy (SEM) of cochlear sensory epithelia were performed as described previously (Senften et al., 2006; Schwander et al., 2007). To generate anti-USP53 antisera, rabbits were coinjected with two synthetic peptides derived from the sequence of mouse USP53 (LNRSQMQTSGRRAPVKLSHD, STASAPRLERVGLSPDVGV). The peptide sequences show no homology with any other protein in publically available databases. The antibodies were purified from the IgG fraction of the antisera by affinity chromatography against each of the two peptides. In addition, two rabbit polyclonal anti-USP53 antibodies, HPA035844 and HPA035845, were obtained from Sigma-Aldrich. All three anti-USP53 antibodies specifically detected green fluorescent protein (GFP)-USP53 fusion protein when expressed in HEK293T cells. Protein expression was evaluated by immunofluorescence analysis with USP53 antibodies as described previously (Senften et al., 2006), except that cochlear tissues were fixed in 2\% PFA for $40 \mathrm{~min}$ at room temperature and incubated with primary antibodies overnight at room temper- ature on a rocking table. Additional antibodies were as follows: mouse anti-Sox2 (Santa Cruz Biotechnology), rabbit anti-myosin VIIa (Proteus Biosciences), mouse anti-calbindin (Sigma), chicken anti-GFP (Rockland), rabbit anti-GFP (Sigma), rabbit anti-GFP (Abcam), rabbit antiZO-1 and anti-ZO-2 (Life Technologies), rabbit anti-occludin (Abcam), rabbit anti-UCHL3 (Cell Signaling Technology), anti-ZO-1 Alexa Fluor 488 conjugate (Life Technologies), anti-FLAG horseradish peroxidase (HRP) conjugate (Sigma), Alexa Fluor 488 and 568 anti-rabbit and antimouse (Life Technologies), Alexa Fluor 488 anti-chicken (Life Technologies), Alexa Fluor 350 and 488 phalloidin (Life Technologies), and HRP-conjugated anti-rabbit (GE Healthcare).

Quantitative RT-PCR. RNA was isolated from finely dissected cochleae using the ARCTURUS PicoPure RNA Isolation kit (Thermo Fisher Scientific) and treated with DNase I (Qiagen). cDNA was synthesized from 72 ng of RNA using the SuperScript IV First-Strand Synthesis System (Thermo Fisher Scientific) and random hexamers. Quantitative PCR was performed using Usp53 isoform-specific primers and iTaq Universal SYBR Green Supermix (Bio-Rad) in a Rotor-Gene 3000 thermal cycler/real-time DNA detection system (Corbett Research). Expression data were normalized using phosphoglycerate kinase $1(P g k 1)$ as a reference gene. Primers included the following: short isoform of Usp53, forward, 5'-GAAGTGTCCTAGTAACTGTGGCC-3', and reverse, 5' GAATGAAAGCAACTGTGATACCCC-3'; long isoform of Usp53, forward, 5' -CGACACAGGGATTTGGTTGATG-3', and reverse, 5' -CAG AGGTGTAGCTCTCATGGG-3'; and Pgk1, forward, 5' -CAACAACAT GGAGATTGGCACA-3', and reverse, 5'-ACAGTAGCTTGGCCAGT CTTG-3'. No difference in the efficiency of primers against the two Usp53 isoforms was detected on serial dilutions of plasmid DNA. The efficiency was close to $100 \%$ for both sets of primers. For quantification purposes, a common threshold fluorescence value for all primer pairs was chosen within the early exponential growth phase. The fractional quantification cycle numbers $C_{q}$ for which the threshold was achieved were extracted from the curve for each primer pair. The fold difference in the abundance of each Usp53 isoform relative to $P g k 1$ was calculated as $2^{\left(C_{q}^{P_{g k 1}}-C_{q}^{U S p 53)}\right.}$, where $C_{q}^{P g k 1}$ and $C_{q}^{U s p 53}$ are quantification cycle numbers for $P g k 1$ and $U s p 53$, respectively. The levels of nonspecific amplification by each primer pair were assessed with no-RT controls (cDNA prepared without reverse transcriptase). The nonspecific amplification levels were $>20$-fold lower than the specific signal for each pair of primers.

In situ hybridization. In situ hybridization (ISH) was performed on $12-\mu \mathrm{m}$-thick cryosections, as described previously (Schwander et al., 2007; Grillet et al., 2009). The RNA probes are complementary to cDNA segments corresponding to amino acid residues 118-474 (probe 1) and 473-797 (probe 2) of mouse USP53.

Immunoprecipitation and Western blot analysis. HEK293T cells were transfected with X-tremeGENE 9 DNA transfection reagent (Roche). After $20 \mathrm{~h}$, cell extracts were prepared in $20 \mathrm{~mm}$ potassium phosphate, $\mathrm{pH} 7.4,500$ $\mathrm{mm} \mathrm{NaCl}, 1 \% \mathrm{NP}-40,0.5 \%$ sodium deoxycholate, $50 \mu \mathrm{M} \mathrm{ZnCl}_{2}$, and MSSAFE protease inhibitor (Sigma). Lysates were diluted 1:4 in $20 \mathrm{~mm}$ potassium phosphate buffer containing $50 \mu \mathrm{M} \mathrm{ZnCl}_{2}$ and precleared with $30 \mu \mathrm{l}$ of protein A-Sepharose (GE Healthcare) for $1 \mathrm{~h}$ at $4^{\circ} \mathrm{C}$. Lysates were incubated with anti-GFP antibody (ab290; Abcam) for $1.5 \mathrm{~h}$ at $4^{\circ} \mathrm{C}$, followed by overnight incubation with $30 \mu \mathrm{l}$ of protein A-Sepharose at $4^{\circ} \mathrm{C}$. Immunocomplexes were washed three times with immunoprecipitation buffer containing $20 \mathrm{~mm}$ potassium phosphate, $125 \mathrm{~mm} \mathrm{NaCl}, 0.25 \% \mathrm{NP}-40,0.125 \%$ sodium deoxycholate, and $50 \mu \mathrm{M} \mathrm{ZnCl}_{2}$ before addition of Laemmli's sample buffer and SDS-PAGE. Proteins were transferred to PVDF membrane with an iBlot system (Life Technologies), and the membrane was blocked with $2 \%$ dry milk (Amresco) for $30 \mathrm{~min}$. The blots were probed with the following antibodies: rabbit anti-GFP (Sigma), rabbit anti-UCHL3 (Cell Signaling Technology), mouse anti-FLAG (Sigma), rabbit anti-ZO-1 and anti-ZO-2 (Life Technologies), and rabbit anti-occludin (Abcam). Primary antibodies and proteins were visualized with HRP-conjugated anti-rabbit antibody (1:20,000; GE Healthcare) using the ECL2 detection system (Thermo Fisher Scientific).

DUB inhibitor assay. HEK293T cells were transfected with X-tremeGENE 9 DNA transfection reagent (Roche). After $24 \mathrm{~h}$, cells were solubilized in $50 \mathrm{~mm}$ Tris, pH 7.5, $150 \mathrm{~mm} \mathrm{NaCl}, 1 \% \mathrm{NP}-40,50 \mu \mathrm{M} \mathrm{ZnCl}_{2}$, $130 \mu \mathrm{m}$ bestatin (Sigma), $1 \mu \mathrm{m}$ pepstatin A (Sigma), and $1 \mathrm{~mm}$ DTT for 20 
min on ice. Lysates from transfected and nontransfected (mock) cells were treated with each of the following DUB inhibitors at a concentration of $50 \mu \mathrm{M}$ : ubiquitin-vinyl methyl ester (Ub-VME), ubiquitinpropargylamide (Ub-PA), or ubiquitin-vinyl sulfone (Ub-VS; Boston Biochem) for $1 \mathrm{~h}$ at $37^{\circ} \mathrm{C}$, boiled in Laemmli's sample buffer for $10 \mathrm{~min}$ at $95^{\circ} \mathrm{C}$, and analyzed by SDS-PAGE and Western blotting.

Culture and injectoporation of cochlear explants. Injectoporation of cochlear explants was performed following recently established protocols (Xiong et al., 2014). Organs of Corti were dissected from P3-P4 wild-type mice, cut into three pieces, and cultured on an uncoated glass coverslip in DMEM/F-12 with $10 \mathrm{ng} / \mu \mathrm{l}$ ampicillin for $4 \mathrm{~h}$ at $37^{\circ} \mathrm{C}$. Subsequently, adherent cochlear explants were placed between two platinum wire electrodes (Surepure Chemetals) and injected with plasmid $(1 \mu \mathrm{g} / \mu \mathrm{l})$ between the second and third row of OHCs using a microinjection pipette (2-3 $\mu \mathrm{m}$ diameter). Pipette and electrodes were positioned using a BX51 upright microscope with a $60 \times$ objective (Olympus), and two micromanipulators (MPC-200; Sutter Instruments). A series of three to five square pulses (15 ms length, $1 \mathrm{~s}$ intervals) with a magnitude of $60 \mathrm{~V}$ was applied using an ECM 830 electroporator (Harvard Apparatus). Organs of Corti were cultured for $8-12 \mathrm{~h}$ in DMEM/F-12, fixed with $4 \%$ PFA, and stained with anti-TJP2 antibody (Life Technologies) and phalloidin to visualize TJs and F-actin in stereocilia, respectively. Samples were imaged using a BX63 fluorescence microscope and CellSens software (Olympus).

Biotin tracer assay. Temporal bones were dissected from mice at 1 month of age, and the round and oval windows were opened in PBS containing $1 \mathrm{mM} \mathrm{CaCl}_{2}(\mathrm{PBS} / \mathrm{C})$. Cochleae were perfused through the round and oval windows with $100 \mu \mathrm{l}$ of $10 \mathrm{mg} / \mathrm{ml}$ EZ-Link Sulfo-NHSLC-Biotin (Pierce Chemical) in PBS/C for 5 min and then flushed with $\mathrm{PBS} / \mathrm{C}$ five times. The temporal bones were then fixed by perilymphatic perfusion with $10 \%$ TCA for $1 \mathrm{~h}$, rinsed once in PBS, and decalcified in $0.12 \mathrm{M}$ EDTA in PBS for $2 \mathrm{~d}$ at room temperature. The tissue samples were rinsed in PBS, incubated in $30 \%$ sucrose in PBS overnight at $4^{\circ} \mathrm{C}$, flash frozen in OCT compound in liquid nitrogen, and sectioned at 15 $\mu \mathrm{m}$. Frozen sections were incubated with streptavidin Alexa Fluor 568 conjugate (Life Technologies) for $1 \mathrm{~h}$ to visualize the distribution of the biotin tracer.

Endocochlear potential. EP recordings followed published protocols with some modifications because of the size and fragility of the mice at P10-P11 (Ohlemiller et al., 2006). Adult mice were anesthetized (60 $\mathrm{mg} / \mathrm{kg}$ sodium pentobarbital, i.p.) and positioned ventrally in a custom head holder. Core temperature was maintained at $37.5 \pm 1.0^{\circ} \mathrm{C}$ using a thermostatically controlled heating pad in conjunction with a probe (model 73A; Yellow Springs Instruments). An incision was made along the midline of the neck, and soft tissues were blunt dissected laterally to expose the trachea and the animal's left bulla. A tracheostomy was then made, and the musculature over the bulla was cut posteriorly to expose the bone. Using a hand drill, a small hole was made in the ventral surface of the bulla, and the opening was expanded to expose the cochlear base. Using a tri-corner pick, a small hole was made in the cochlear capsule directly over the scala media of the lower basal turn. Glass capillary pipettes $(40-80 \mathrm{M} \Omega$ ) filled with $0.15 \mathrm{M} \mathrm{KCl}$ were mounted on a hydraulic microdrive (FHC) and advanced until a stable positive potential was observed that did not change with increased electrode depth. The signal from the recording electrode was led to an AM Systems model 1600 intracellular amplifier. A silver/silver chloride ball electrode inserted into the neck muscles served as ground. Mice tested at P10-P11 were unstable under sodium pentobarbital, so that a ketamine-xylazine ( 80 and $15 \mathrm{mg} / \mathrm{kg}$, respectively) mouse mixture was used in these mice.

Noise exposure. Mice were exposed fully awake to $8-16 \mathrm{kHz}$ octave band noise for $2 \mathrm{~h}$ at $98 \mathrm{~dB}$ SPL. Noise exposure was performed in an Industrial Acoustics double-walled sound booth. Up to two $30 \times 19 \times 13$ $\mathrm{cm}$ reverberant plastic cages containing one mouse each were suspended $50 \mathrm{~cm}$ below an exponential horn (Selenium Corneta HM4750-SLF). Noise was generated digitally using custom Labview routines and presented using a Tucker-Davis Technologies RZ6 in combination with a Crown Audio power amplifier. Sound level was monitored in real time by Brüel and Kjær Type 2203 sound-level meter and tracked by custom software. Mice were 7 weeks of age at the time of exposure. For the ABR measurement, animals were anesthetized with a mixture of ketaminexylazine ( 80 and $15 \mathrm{mg} / \mathrm{kg}$, i.p., respectively) and placed in a prone position on a platform with an ES-1 free-field speaker (Tucker-Davis Technologies) $7 \mathrm{~cm}$ directly lateral from the right ear. Subdermal platinum electrodes (Grass Instruments) were placed behind the right pinna (reference), on the vertex (active), and under the skin of the back (ground). A rectal probe was used to monitor temperature that was maintained near $38^{\circ} \mathrm{C}$ using a direct current-based isothermal pad (FHC). Tone bursts $5 \mathrm{~ms}$ in duration $\left(0.5 \mathrm{~ms} \cos ^{2}\right.$ rise/fall $)$ were presented 500-1000 times at 20/s in descending intensity using a $5 \mathrm{~dB}$ minimum step size until wave I of the ABR could no longer be discerned visually. Recording used Biosig32 and Tucker-Davis Technologies hardware. Baseline ABR tests were obtained at 5, 10, 20, and $28.3 \mathrm{kHz} 2 \mathrm{~d}$ before exposure (preexposed) and $14 \mathrm{~d}$ after (exposed).

\section{Results}

A missense mutation in the Usp53 gene underlies hearing loss in mambo mice

The mambo mouse mutant was generated on a C57BL/6/6J background in a large-scale mouse ENU-mutagenesis screen for novel recessive deafness traits (Schwander et al., 2007). mambo mice presented with a low acoustic startle response (ASR), a rapid and involuntary reflex involving the contraction of muscles evoked by a loud sound (Schwander et al., 2007). Because reduced ASR can be caused by deficits in emotional processing or motor or auditory function, the mice were tested for ABR, which is a measure of sound-evoked neuronal activity (Zheng et al., 1999). ABR thresholds $>90 \mathrm{~dB}$ SPL were measured for a broadband click stimulus, indicating severe hearing impairment (Schwander et al., 2007). Heritability testing of mambo mice on the C57BL/6J background revealed that they inherit their deafness phenotype recessively (Schwander et al., 2007).

To map the affected genomic locus, we outcrossed affected mambo mice to the BALB/cByJ mouse strain. The resulting F1 hybrids were intercrossed to generate F2 mice for ABR phenotyping and linkage analysis with SNP markers as described previously (Wiltshire et al., 2003; Schwander et al., 2007). Consistent with a fully penetrant recessive trait, we found $\sim 24 \%$ ( 13 of 55 ) of the F2 animals to be affected in ABR tests. SNP mapping of the F2 progeny identified a $1.6 \mathrm{Mb}$ interval (122.3-123.9 Mb) on chromosome 3 that segregated with the mambo phenotype (Fig. $2 A$ ). We next designed primers for all annotated $(n=12)$ and predicted $(n=3)$ genes in the interval, amplified mRNA from the organ of Corti of affected mambo and C57BL/6J mice by RT-PCR and sequenced the amplicons (Fig. 2B; and data not shown). For some genes, we also screened genomic DNA for mutations by sequencing exons, intron/exon boundaries, and most of the $5^{\prime}$ and $3^{\prime}$ untranslated regions. We identified only one mutation: a $\mathrm{T}>\mathrm{A}$ transversion (c.682T $>\mathrm{A}$ ) located in coding exon 7 of the Usp53 gene (p.C228S; Fig. 2C). The mambo mutation introduces a TspRI restriction site that enabled us to genotype mice by PCRrestriction fragment length polymorphism (PCR-RFLP) assay (Fig. 2D). The point mutation was uniquely homozygous in mice that displayed the deafness phenotype (data not shown). Based on these findings, we conclude that the point mutation in the Usp53 gene underlies the deafness phenotype in mambo mice.

\section{Progressive hearing loss and $\mathrm{OHC}$ dysfunction in mambo mice}

To investigate the nature of hearing impairment in mambo mice, we determined ABR thresholds in 2.5-, 4-, and 8-week-old mice in response to broadband click stimuli starting at $90 \mathrm{~dB}$ SPL and then decreasing in intensity. The recorded potentials were plotted 
against the response time at any given sound intensity (Fig. 3A). The first peak (I) represents the activity of the auditory nerve; the subsequent peaks (II-IV) arise in neuronal populations of the auditory brainstem. At P18, ABR thresholds were elevated in homozygous mambo mice $(62 \pm 4 \mathrm{~dB}$ SPL, mean $\pm \mathrm{SEM}, p<0.005$, two-tailed $t$ test) when compared with heterozygous littermates $(39 \pm 4 \mathrm{~dB})$ or age-matched wild-type mice ( $42 \pm 5 \mathrm{~dB}$; Fig. 3B). By P30, homozygous mambo mice were profoundly hearing impaired (ABR thresholds $>80 \mathrm{~dB}$ ), and, by P60, most of them were deaf (ABR thresholds $>90 \mathrm{~dB}$; Fig. 3B). Analysis of ABRs elicited by pure tones between 4 and $32 \mathrm{kHz}$ revealed that mambo mice were equally affected across all frequencies (Fig. 3C). We conclude that the hearing loss in mambo mice is early onset and rapidly progressive in nature and affects all tested frequencies.

Disruption of the first peak of the ABR waveform (Fig. 3A) could be caused by defects in hair cells and/or spiral ganglion neurons. One possibility is that the decreased auditory sensitivity in mambo mice is attributable to compromised $\mathrm{OHC}$ function, which leads to a loss of cochlear amplification. Therefore, we recorded DPOAEs, which depend on the mechanical activity of OHCs. DPOAEs were present in 2-month-old wild-type and heterozygous mambo mice but were absent in homozygous mutant animals at all of the frequencies analyzed $(6-28 \mathrm{kHz}$; Fig. $3 D, E)$. The results indicate that the functional impairment of OHCs contributes to hearing loss in mambo mice, although $\mathrm{OHC}$ dysfunction alone does not cause complete deafness. Aside from hearing loss, no differences between mambo and wild-type mice were observed in gross neurologic function and reflexes. In particular, vestibular function was intact (Schwander et al., 2007).

\section{Defects in hair cell morphology in mambo mice}

The abnormal DPOAE recordings observed in mambo mice suggested that the integrity of cochlear hair cells might be compromised. Therefore, we analyzed the morphology of hair cells in cochlear sensory epithelia from homozygous mambo mice and age-matched wild-type mice by SEM (Fig. 4A). At P5, the cochlear sensory epithelium was normally patterned into one row of inner hair cells (IHCs) and three rows of OHCs, and hair bundles exhibited the characteristic staircase-like arrangement of stereocilia. By P11, clear changes in the morphology and number of OHCs became evident in mambo mice (Fig. $4 A$, arrow). OHCs showed signs of degeneration, including ruffling of the apical cell membrane and fused stereocilia (Fig. $4 A$, arrowhead). In addition, OHCs occasionally displayed subtle defects in bundle polarity (data not shown). TEM analysis of the cochlear duct at P10 revealed incomplete and lumpy chromatin condensation in $\mathrm{OHC}$ nuclei, indicative of early apoptotic changes (Fig. 4B, arrow-

Mambo locus
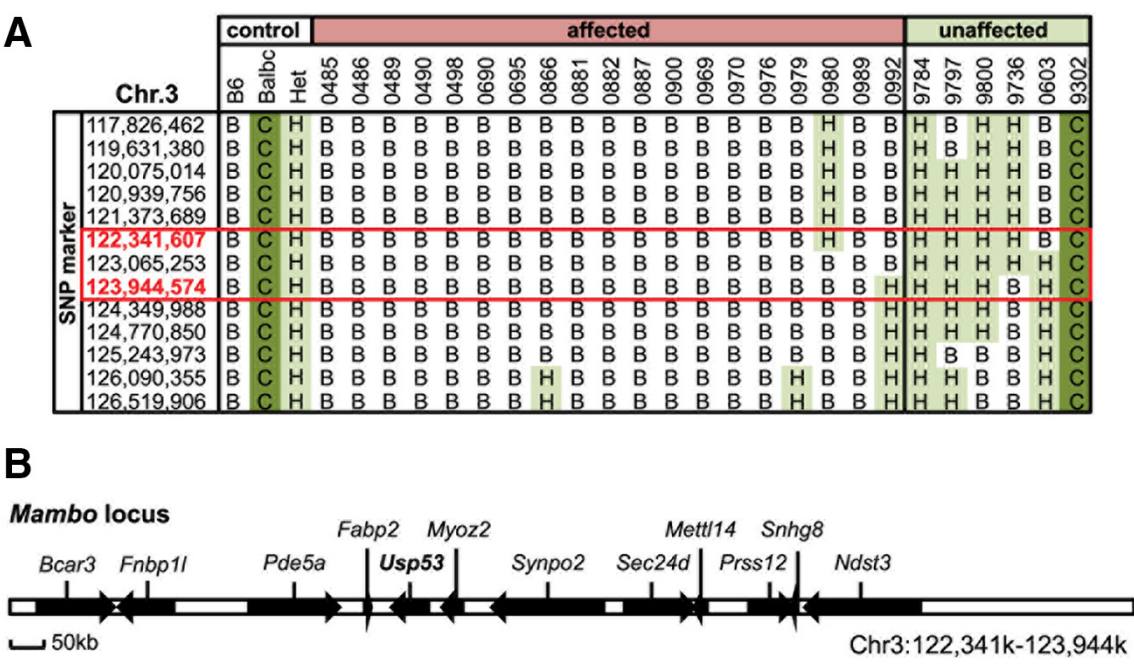

Chr3:122,341k-123,944k

Figure 2. mambo mice carry a missense mutation in the Usp53 gene. $\boldsymbol{A}$, Mapping of the mambo locus. The diagram shows the fine mapping of the region of chromosome $3(\mathrm{Chr} 3)$ linked to the mutant phenotype. mambo mice (generated on a typing. DNA from affected and unaffected F2 mice and control mice was analyzed with SNP markers that distinguish between the mutant phenotype is highlighted with a red box. $\boldsymbol{B}$, The annotated genes in the mapped interval on mouse chromosome

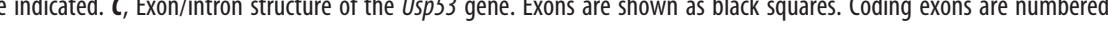
exon 7 (box). D. The mambo mutation introduces a TspRI restriction site, facilitating genotyping of the mice by PCR-RFLP. An agarose gel picture shows the resolved fragments from TspRI PCR-RFLP analysis on genomic DNA of a wild-type (WT; 310 bp), a heterozygous (HET; 110, 200, and 310 bp), and a homozygous (MUT; 110 and 200 bp) mambo mouse (arrowheads).

heads). However, no signal for cleaved caspase-3 was observed in hair cells of mutant cochlea by immunohistochemistry (data not shown), suggesting that the lack of USP53 triggers OHC death via a caspase-independent pathway.

We next analyzed hair cell morphology by staining inner ear sections from 1- and 3-month-old mice with hematoxylineosin (Fig. 4C). Consistent with the SEM results, we observed a significant loss of OHCs in the cochlea of mambo mice at 1 month of age, whereas IHCs and spiral ganglion neurons appeared unaffected (Fig. 4C, top). To evaluate survival of hair cells and supporting cells, we counted cell bodies in serial sections through the cochlear duct from wild-type and mambo mice $(n=4$ and 4$)$. In addition to the loss of OHCs $(p<0.005$, two-tailed $t$ test), there was a small but statistically significant decrease in the number of Deiters' cells $(p<0.05)$ but not IHCs $(p=0.8$; Fig. $4 D$ ). By 3 months of age, most cochlear hair cells were missing and degeneration of the entire organ of Corti was evident, indicating that $\mathrm{OHC}$ loss is followed by the degeneration of IHCs in adult mice (Fig. 4C, row 2, arrowheads). Degeneration of peripheral axons and somata of spiral 
A

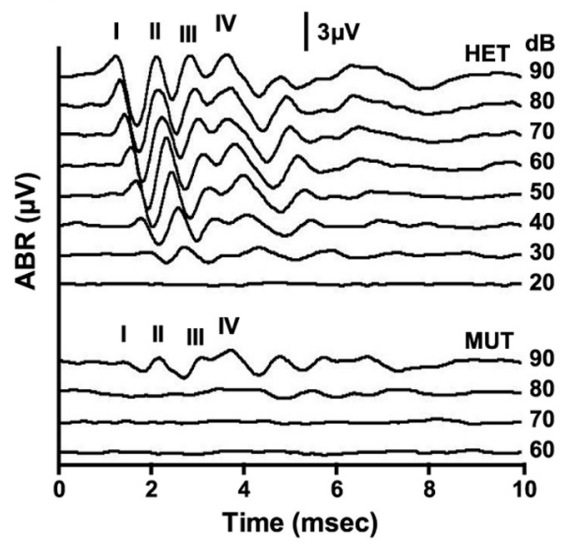

D

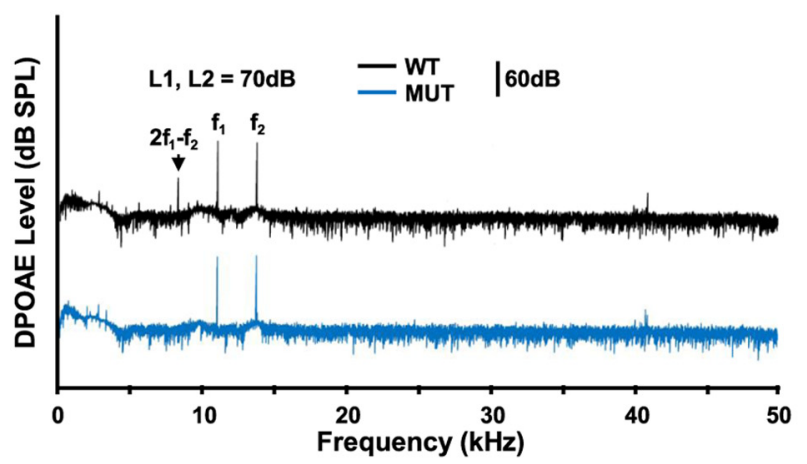

B

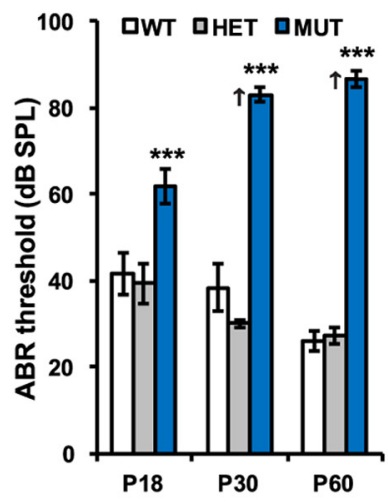

C

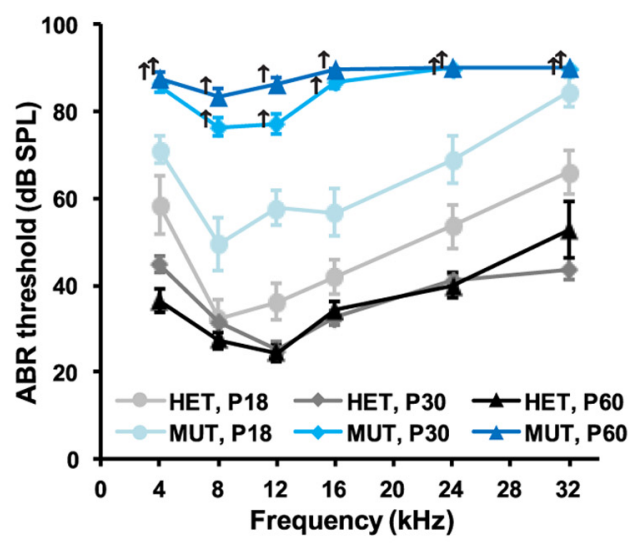

E

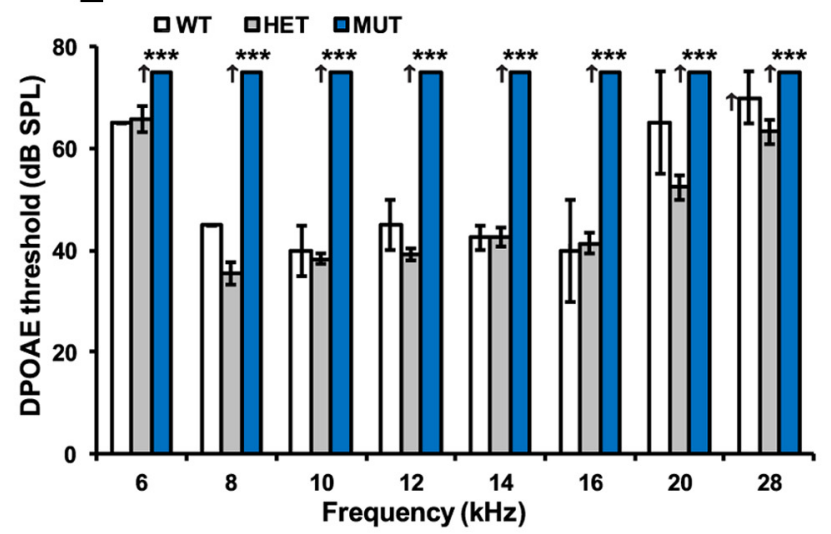

Figure 3. Analysis of auditory function in mambo mice. $\boldsymbol{A}$, Representative ABR waveforms of 8-week-old heterozygous (HET) and homozygous mambo mutant (MUT) mice in response to broadband clickstimuli. Homozygous mutants showed ABR thresholds $>80 \mathrm{dBSPL}$. ABR waves I-IV are indicated. B, Average ABR thresholds in P18, P30, and P60 mice (WT, $n=5 ;$; HET, $n=7 ;$; MUT, $n=12$; mean \pm SEM). Thresholds were elevated across frequencies in homozygous mutants at P18 and progressively increased with age. ${ }^{* * *} p<0.005$, significant differences between HET and MUT groups. No significant differences between WT and HET groups were observed ( $p>0.1$ for all ages). Individual mice in the P30 and P60 MUT groups displayed auditory thresholds beyond the range of our measurements ( $>90 \mathrm{~dB}$ SPL). Arrows indicate that the mean thresholds are higher than shown on the graph (arrows). C, Average pure tone-evoked ABR thresholds in heterozygous (HET) and homozygous (MUT) mambo mice. D, Representative DPOAE response spectra for a 2-month-old wild-type (WT; black trace) and mambo mouse (blue trace) at a single stimulus condition (median primary frequency of $12 \mathrm{kHz}$ ). The cubic distortion product $\left(2 f_{1}-f_{2}\right.$, arrow), which is present in wild-type mice, is absent in recordings from mambo mice. $E$, DPOAE thresholds were highly elevated in MUT mice at all analyzed frequencies (arrows). ${ }^{* * *} p<0.005$, significant differences between HET and MUT mice (WT, $n=2 ; H E T, n=15 ;$ MUT, $n=14$; mean \pm SEM). Primary frequencies were maintained at an $f_{2} / f_{1}$ ratio of 1.22 , and the intensities were equal.

ganglion neurons was widespread (Fig. $4 C$, rows 2 and 3 , arrows). Because there were no obvious morphological abnormalities in sensory neurons of the early postnatal inner ear, initial hearing loss in mambo mice is likely caused by defective hair cell function. Finally, the gross anatomy of the vestibular end organs appeared normal, which is consistent with the nonsyndromic hearing loss phenotype of mambo mice (Fig. $4 C$, row 4; Schwander et al., 2007).

Immunofluorescence staining of cochlear whole mounts revealed that hair cells in mambo mice differentiate normally and display specific hair cell markers, such as myosin VIIa, but start to degenerate at approximately P8 (Fig. $4 E$, top panels). At P10, OHCs were found frequently in aberrant positions among Sox2positive nuclei of Deiters' cells, indicating disruption of cochlear microarchitecture (Fig. 4E, bottom panels). OHCs are lost progressively along the cochlea in a mosaic pattern, rather than following a basal-to-apical gradient (data not shown). Altogether, these data support the hypothesis that the degeneration of OHCs is the initial trigger of pathological changes in the cochlea, which is reflected in the reduced DPOAE responses in mambo mice.
The mambo mutation affects the putative catalytic domain of USP53

Several mRNA isoforms of Usp53 have been described. The longest isoform that we could amplify from mouse cochlea is identical to NM_133857.3 and comprises 15 coding exons, encoding a protein of 1069 aa (Fig. 5A). The USP53 protein has a predicted $\mathrm{N}$-terminal USP catalytic domain (amino acids 1-348) and belongs to the USP superfamily of DUBs (Quesada et al., 2004; Reyes-Turcu et al., 2009). The mambo mutation (c.682T $>A$ ) introduces a missense mutation (p.C228S) in coding exon 7 of the Usp53 gene, which encodes part of the USP catalytic domain of USP53 (Fig. 5A). A shorter cloned cDNA for Usp53 (AK045953) contains coding exons 1-7, which encode a putative protein fragment that consists of an incomplete N-terminal catalytic domain (amino acids 1-274) and nine extra amino acids resulting from usage of an alternative $3^{\prime}$ splice site in exon 7 (Fig. 5B). These are the only known Usp53 isoforms that contain exon 7, which is affected by the mambo mutation. We assessed the relative abundance of the short and long (full-length) Usp53 isoforms with respect to 
the reference gene $P g k 1$ in cochlea of wild-type mice at P6 by RT-qPCR (Fig. $5 C)$. Levels of full-length Usp53 mRNA were at least 10 -fold higher compared with the short isoform. A 10-fold difference in the abundance of the two isoforms was also detected in heterozygous and homozygous mambo mice in the age range $\mathrm{P} 4-\mathrm{P} 8$ (data not shown). The data indicate that full-length Usp53 is the predominant isoform in the cochlea and likely most relevant to inner ear function.

We found USP53 orthologs solely in vertebrate genomes (human, mouse, rat, chicken, Xenopus laevis, and zebrafish) but not in arthropods (Drosophila melanogaster) or nematode (Caenorhabditis elegans). Multiple sequence alignments showed that the affected residue, C228, is conserved among all USP53 orthologs (Fig. 5D). BLAST (basic local alignment search tool) database searches showed that the catalytic domain of USP53 has the highest sequence similarity (65\% identical and $78 \%$ similar residues) to the catalytic domain of USP54, a protein of unknown function (data not shown). In addition, USP53 and USP54 show significant sequence similarity to echinus, a Drosophila protein required for ommatidial rotation and programmed cell death in the fly eye, within their respective catalytic domains (Copeland et al., 2007; Montrasio et al., 2007). The sequence similarity to echinus extends to the C-terminal tail region in USP54 but not in USP53, indicating that the two DUBs may have acquired distinct functions. A functionally essential histidine residue of the His-box, which contributes to the recognition of the $\mathrm{C}$ terminus of ubiquitin, is absent in both USP53 and USP54 (Fig. 5A), suggesting that these proteins may lack catalytic activity (Hu et al., 2002; Quesada et al., 2004).

USP catalytic domains share a common conserved fold, resembling an opened right hand with thumb, palm, and fingers subdomains (Hu et al., 2002). The catalytic triad is formed by the thumb (Cys) and palm subdomains (His, Asp/Asn; Fig. 5A, arrows), whereas the fingers subdomain serves as the primary ubiquitin interaction site. Two adjacent double cysteine motifs (CXXC) in the fingers subdomain coordinate one zinc ion in many of the USPs (Avvakumov et al., 2006; Renatus et al., 2006). USP53 contains two double cysteine motifs in a region that overlaps with the fingers subdomain of other USP proteins, although the second double cysteine motif diverges from CXXC to CXXXC (Ye et al., 2009). Strikingly, the mambo mutation converts the second cysteine in the CXXXC motif into a serine (Fig. 5D). Thus, a similar zinc binding site may be present in USP53, and ubiquitin binding rather than catalysis may be affected by the mambo mutation.
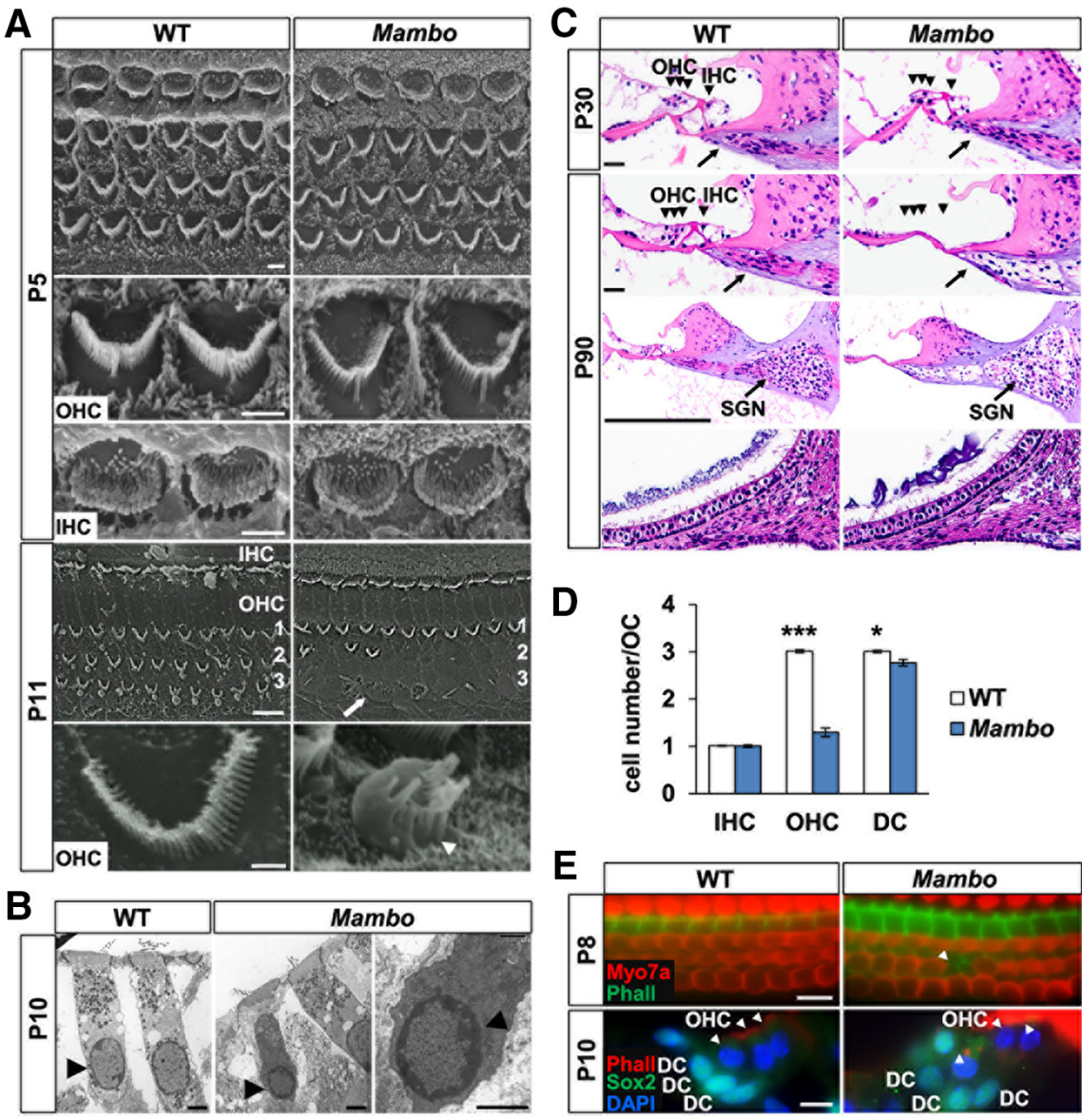

Figure 4. Hair cell degeneration in mambo mice. $A$, Scanning electron micrographs of cochlear whole mounts of P5 and P11 wild-type (WT) and mambo homozygous mutant mice. $\boldsymbol{B}$, Electron microscopic characterization of $\mathrm{OHC}$ on ultrathin sections of Pild-type and mutant cochlea. C, Sagittal inner ear sections from wild-type and mambo mice at P30 and P90 were stained with serial hematoxylin-eosin sections of cochleae from 1-month-old wild-type and mambo mice. The average number of each cell , F-actin) and an antibody against My07A (red) to label hair cells. Bottom row, Sagittal sections through the cochlea of P10

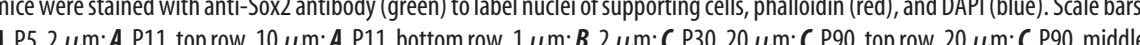
row, $200 \mu \mathrm{m} ;$ and $C$, P90, bottom row, $20 \mu \mathrm{m} ; E, 10 \mu \mathrm{m}$.

To test the catalytic activity of USP53, we performed a DUB inhibitor assay. DUB inhibitors contain ubiquitin conjugated to a reactive group, such as vinyl methyl ester (Ub-VME). During ubiquitin binding to the DUB, the active-site cysteine will react with the reactive group and form a covalent complex between the DUB and the ubiquitin molecule, which can be detected as a shift in molecular weight by Western blotting. Therefore, we treated lysates from HEK293T cells overexpressing wild-type GFP-USP53 with different DUB inhibitors, followed by Western blotting with antibodies against USP53 or UCHL3, another DUB, which served as a positive control. In samples treated with DUB inhibitors, a shift in molecular size was observed for UCHL3 but not for USP53 (Fig. 5E), suggesting that USP53 is a catalytically inactive DUB. These results are consistent with previous enzymatic activity studies showing that USP53 is devoid of catalytic activity against ubiquitin- $\beta$-galactosidase fusion protein (Quesada et al., 2004). 
A

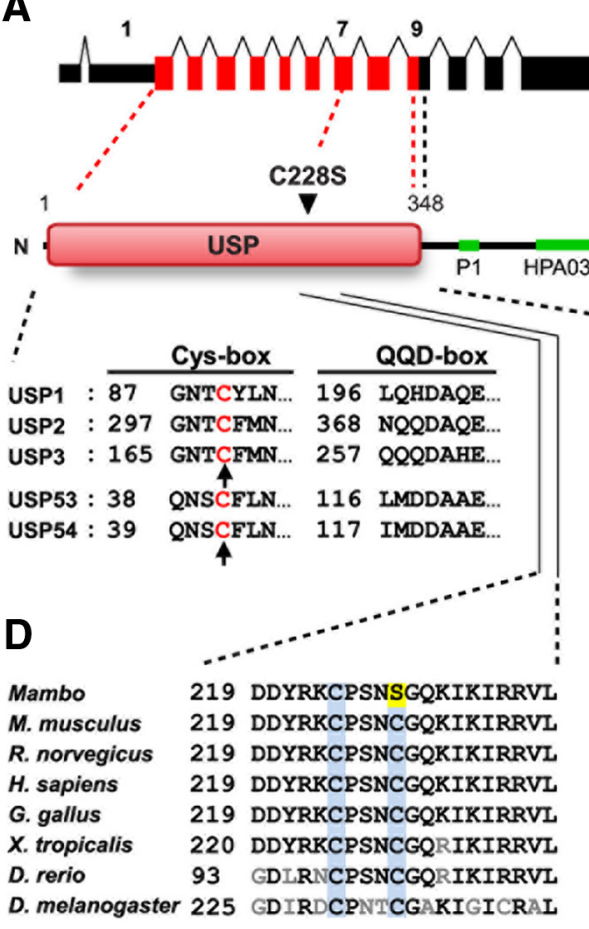

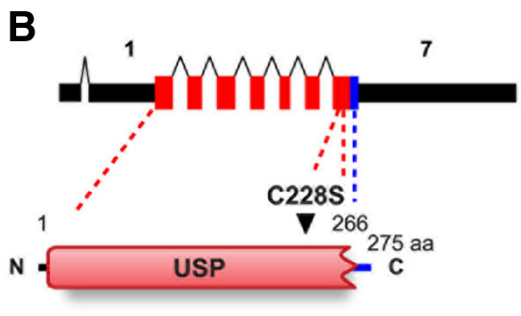

SH3 binding site (PPPLPP)

1069 aa

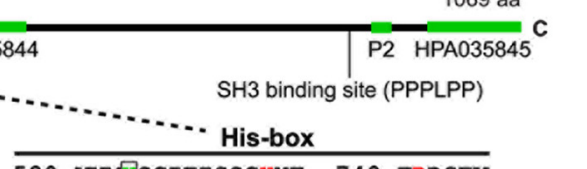

580 VVMFITITISSGHYT... 749 FDDSEV...

560 VSNESG-TTMGGHYT... 587 FNDSSV...

459 VVVHHGSGVGSGHT 485 FNDSTV

289 LHLVGMICYTSRHYC... 317 FDDAHV..

290 LYLUGMICYYGKHYS... 318 FDDAHV...
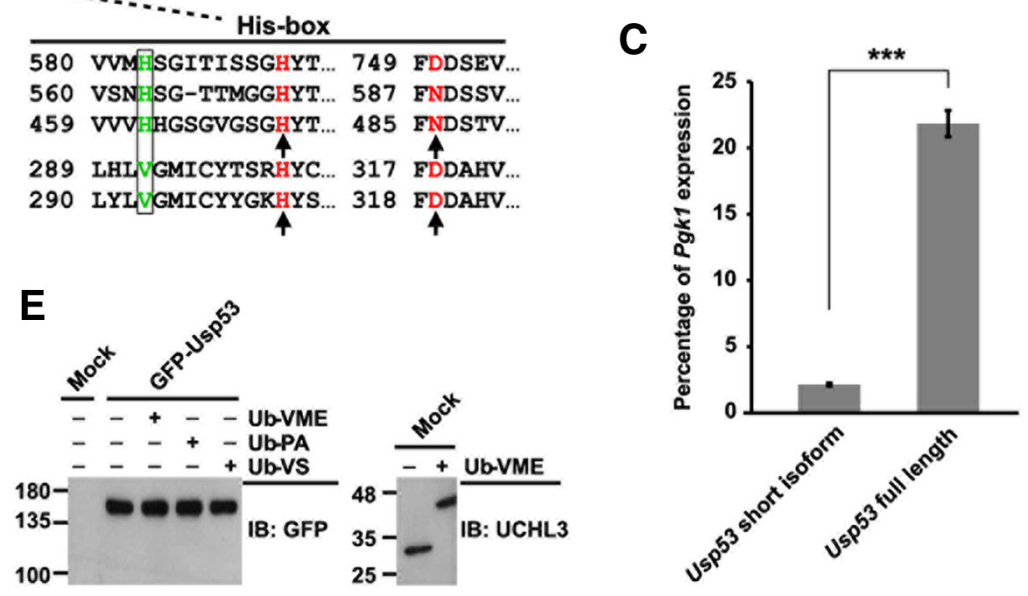

Figure 5. mambo mice carry a mutation in the catalytic domain of USP53. A, Exon/intron structure of mouse Usp53 full-length transcript (NM_133857.3) and the deduced domain structure of USP53 protein. USP53 contains a predicted USP domain (red) encoded by coding exons 1-9 (red boxes). The mambo mutation (p.(228S) is indicated (arrowhead). The epitopes for the commercial USP53 antibodies HPA035844 and HPA035845 (Sigma), as well as the two peptides used to generate the custom polyclonal antibody Rb111 against USP53 (P1 and P2), are indicated by green bars. The predicted SH3 domain binding site is represented by a vertical line. The catalytic domain of DUBs consists of three well conserved regions: Cys-box, QQD-box, and His-box. The catalytic triad residues are highlighted in red (arrows). In USP53 and USP54, a conserved histidine residue of the His-box is absent (green), indicating that they lack catalytic activity. B, A short Usp53 transcript (AK045953) is produced by the use of an alternative 3' splice site downstream of exon 7, adding a small stretch of coding sequence (blue box) and a long 3' UTR. The corresponding putative protein consists of an incomplete USP catalytic domain and 9 extra amino acids. C, RT-qPCR analysis. mRNA levels of full-length and short Usp53 isoforms in cochlea from P6 wild-type mice were quantified in relation to the reference gene Pgk1. Levels of Usp53 full-length isoform ( $21 \pm 1 \%)$ were at least 10 -fold higher than those of the short isoform $(2.1 \pm 0.1 \%$; mean \pm SEM; $n=6$ mice; $* * * p<$ $10^{-8}$, two-tailed $t$ test). D, The cysteine (228 mutated in mambo mice (yellow) is part of a highly conserved double cysteine motif (blue). $\boldsymbol{E}$, DUB inhibitor assay. HEK293 cells were either mock transfected or transfected with GFP-USP53 construct, and lysates were incubated in the absence or presence of DUB inhibitors (Ub-VME, Ub-PA, and Ub-VS). Proteins were separated by SDS-PAGE followed by Western blotting with the indicated antibodies. Note that endogenously expressed UCHL3 but not GFP-USP53 exhibited a mobility shift of $\sim 10 \mathrm{kDa}$ after incubation with DUB inhibitor. IB, Immunoblot.

mambo is expressed broadly in the inner ear

To examine the expression pattern of Usp53 in the mouse inner ear, we performed ISH assays on frozen sagittal sections from wild-type mice at P4. Identical results were obtained using two independent RNA probes that hybridize to nonoverlapping regions of Usp53 mRNA (Fig. 6A). Expression of Usp53 mRNA was detected at intermediate levels in hair cells and a particular subset of cochlear supporting cells, including pillar cells, Deiters' cells, and Hensen's cells (Fig. 6B-I). Usp53 was also expressed in the cochlear nerve and fibrocytes of the spiral ligament, but no expression was observed in stria vascularis and spiral limbus (Fig. $6 B-D, F-H$ ). Nonspecific hybridization signal in the tectorial membrane and Reissner's membrane was also observed in sections incubated with a Usp53 sense probe, which served as a negative control (Fig. $6 J-M)$. An example of ISH for a hair cell-specific gene, Pejva$\mathrm{kin}$, is given for comparison (Fig. $6 \mathrm{~N}-\mathrm{Q}$ ). A schematic representation of the Usp53 expression pattern in the mouse organ of Corti at P4 is given in Figure 6, $R$ and $S$.

USP53 localizes to TJs in cochlear epithelial cells

To examine the subcellular distribution of USP53, we expressed a cDNA encoding GFP-USP53 fusion protein in hair cells and supporting cells by injectoporation of cochlear explants from $\mathrm{P} 4$ wildtype mice following a recently described protocol (Fig. 7A, B; Xiong et al., 2014). We found that GFP-USP53 accumulated at the apical cell borders in transfected hair cells and supporting cells, and its localization overlapped precisely with endogenously expressed TJP2 (Fig. 7C). A $z$-axis analysis of the vertical distribution of GFP-USP53 showed that the fusion protein specifically localized to the apicalmost region $(\sim 1 \mu \mathrm{m})$ of hair cells (Fig. $7 D)$ and supporting cells, in which the apical processes of these cells are joined by TJs. To verify whether the association of USP53 with TJs is tissue or cell-type specific, we analyzed its subcellular localization in heterologous cells. We chose Madin-Darby canine kidney (MDCK) cells for this analysis because they form a polarized epithelium with TJs when grown to confluence. In transfected MDCK cells, GFP-USP53, but not GFP alone, prominently colocalized with TJP2 at TJs (Fig. 7E, arrows) and sporadically at intracellular puncta (Fig. 7E, arrowheads), indicating that USP53 and TJP2 might be able to form protein complexes at these subcellular sites in different types of epithelial cells.

To verify whether heterologously expressed USP53 (GFP-USP53) reflects endogenous USP53 distribution in the organ of Corti, we generated rabbit polyclonal antisera (Rb111) against two peptides from the $\mathrm{C}$-terminal tail domain of mouse USP53 (Fig. 5A). The antisera were affinity purified against each peptide separately. In addition, we tested two commercially available antibodies (HPA035844 and HPA035845; Sigma) that recognize different epitopes in the $\mathrm{C}$-terminal tail of the protein (Fig. $5 A)$. The affinity-purified antibodies specifically detected 
USP53 in extracts from transfected HEK293T cells (Fig. 8A; and data not shown). The antibodies were also effective in immunohistochemistry as they strongly labeled cell borders of cells overexpressing GFP-USP53 in injectoporated cochlear explants (Fig. $8 B$; and data not shown). Immunolabeling of acutely dissected wild-type organs of Corti revealed a circumferential staining pattern for endogenous USP53 in areas of cell-cell contacts between hair cells and Deiters' cells (Fig. 8C, left, $D$ ). No alterations in the distribution of USP53 were observed in heterozygous and homozygous mambo mice (Fig. 8C). Furthermore, no signal was observed with preimmune serum or secondary antibody alone (Fig. 8D; and data not shown). Together, these findings suggest that USP53 can be recruited to TJs in epithelial cells of the inner ear and in heterologous epithelial cells.

Several TJPs have been localized to the inner ear, and a number of them have been implicated in hearing, including members of the claudin family (claudin-9, claudin-11, and claudin-14), occludin, tricellulin, ILDR1, and TJP2 (Fig. 1). Mutations in the respective genes lead to deafness in mice and humans (Wilcox et al., 2001; Ben-Yosef et al., 2003; Gow et al., 2004; Kitajiri et al., 2004, 2014; Nakano et al., 2009; Walsh et al., 2010; Borck et al., 2011; Morozko et al., 2015). To verify whether USP53 acts in a common pathway with any of these proteins, we searched for biochemical interactions. First, we sought to map the domain in USP53 that mediates its association with TJs by expressing various USP53 fragments as GFP fusions in the cochlear sensory epithelium (Fig. 9A). Although full-length USP53 and its C-terminal tail domain localized to cellular junctions, the catalytic domain and GFP alone were distributed evenly in the cytoplasm, indicating that the tail domain controls subcellular localization of USP53. Consistent with these findings, the mambo mutation, which affects the catalytic domain, did not perturb USP53 localization at the junctions. Analysis of the USP53 primary sequence using Scansite 3 (Obenauer et al., 2003) with high-stringency criteria identified a putative binding site for $\mathrm{SH} 3$ domains (Fig. $5 \mathrm{~A}$ ). This finding seemed intriguing because of the fact that the major junctional scaffolding proteins TJP1 and TJP2 contain SH3 domains (Jesaitis and Goodenough, 1994). However, disruption of the SH3 binding site did not alter the subcellular localization of USP53 (Fig. $9 A$ ), indicating that other elements in the tail domain promote its recruitment to TJs.

\section{USP53 binds TJP1 and TJP2}

Based on the expression and distribution of USP53 in cochlear epithelial cells, we next asked whether the DUB is part of the multiprotein complex of TJs. We overexpressed full-length USP53, catalytic domain, C-terminal tail, USP53-mambo, and USP53 lacking the

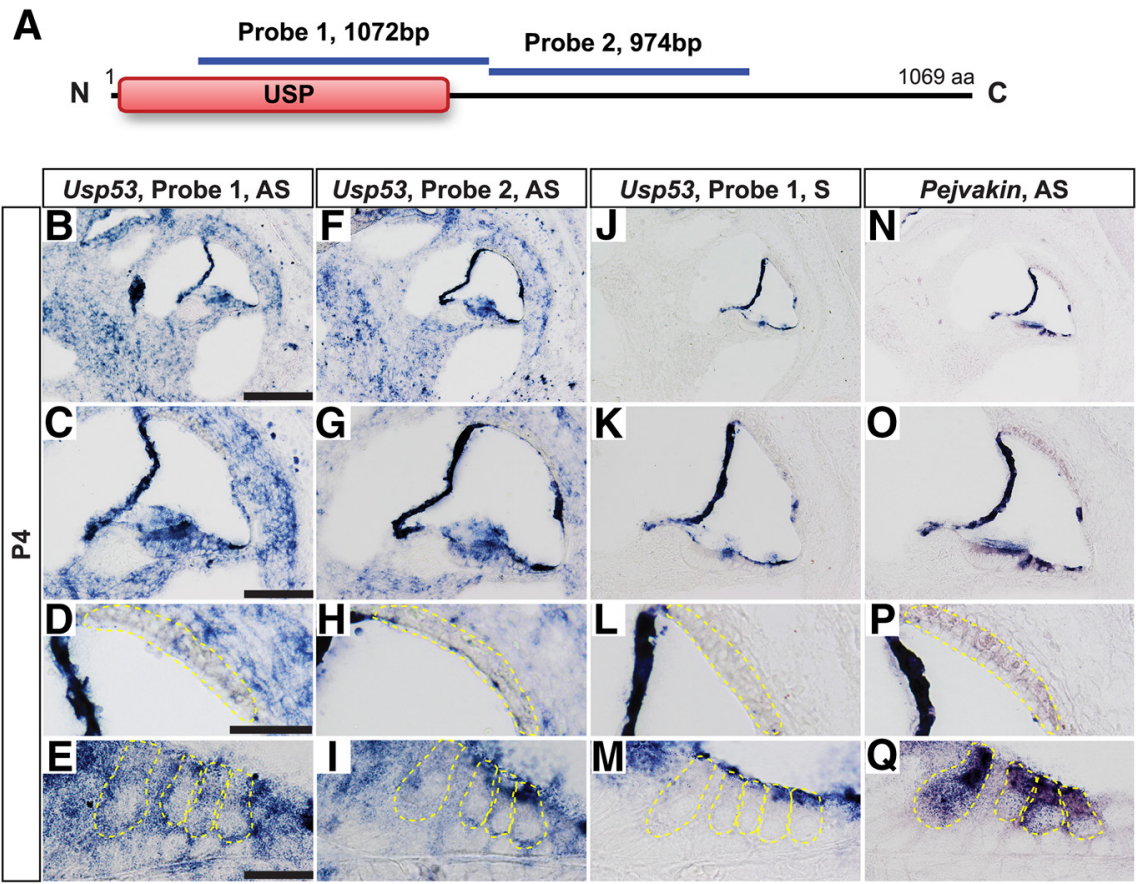

$\mathbf{R}$
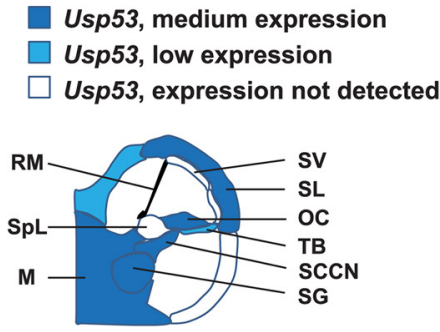

Figure 6. Analysis of Usp53 expression by ISH. A, Schematic diagram of mouse USP53 with the locations of two non-0verlapping cells; CC, Claudius cells; BM, basilar membrane; PC, pillar cells; DC, Deiters' cells. Scale bars: (in B) $\boldsymbol{B}, \boldsymbol{F}, \boldsymbol{J}, \boldsymbol{N}, 200 \mu \mathrm{m}$; (in C) C, G, $\boldsymbol{K}$, 0, $100 \mu \mathrm{m}$; (in D) $\boldsymbol{D}, \boldsymbol{H}, \boldsymbol{L}, \boldsymbol{P}, 50 \mu \mathrm{m}$; (in $\boldsymbol{E}) \boldsymbol{E}, \boldsymbol{I}, \boldsymbol{M}, \mathbf{Q}, 20 \mu \mathrm{m}$.

predicted SH3 binding site as GFP fusions in HEK293T cells and performed coimmunoprecipitation assays for endogenously expressed TJPs. Both native TJP1 and TJP2 coprecipitated with wildtype and full-length mutant USP53 proteins, as well as with the C-terminal tail, but not with the catalytic domain or GFP alone. In contrast, the transmembrane TJ protein occludin failed to associate with USP53 (Fig. 9B,C). Coimmunoprecipitation of overexpressed FLAG-tagged TJP2, rather than native TJP2, with GFP-USP53 confirmed the specific interaction between USP53 and TJP2 (Fig. 9D). No interactions were observed between USP53 and occludin, claudin-9, or claudin-14 by coimmunoprecipitation (data not shown), suggesting that recruitment of USP53 to TJs likely occurs through TJP1/2 binding. Serial C-terminal deletion mutants of mouse USP53 were generated to map the TJP2 interaction site to an $\sim 300$ aa region adjacent to the catalytic domain (Fig. 9E). The findings are consistent with the results from injectoporation studies and suggest that USP53 associates with TJ adaptor proteins via its C-terminal domain, possibly regulating their levels or activity. 
A

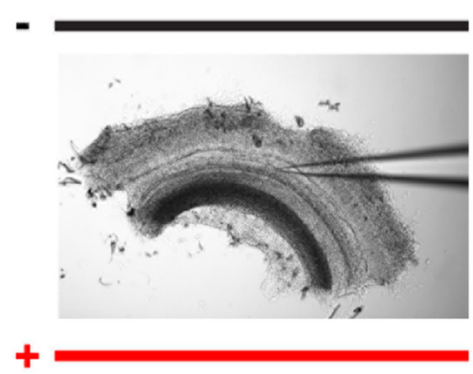

B

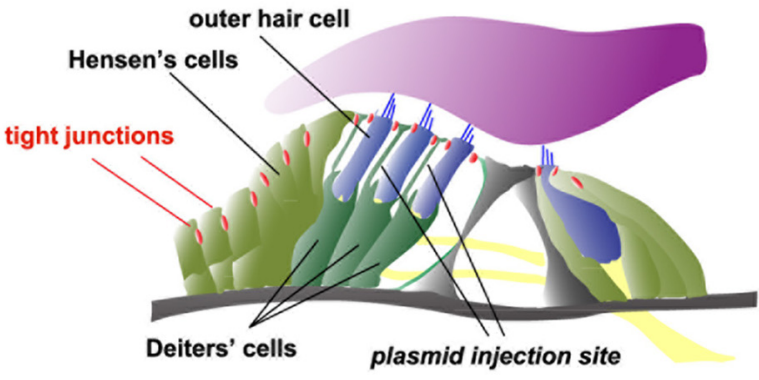

C

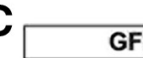

GFP
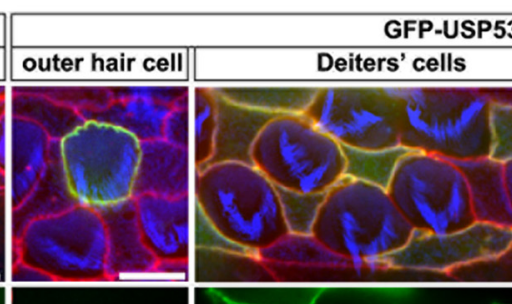

53
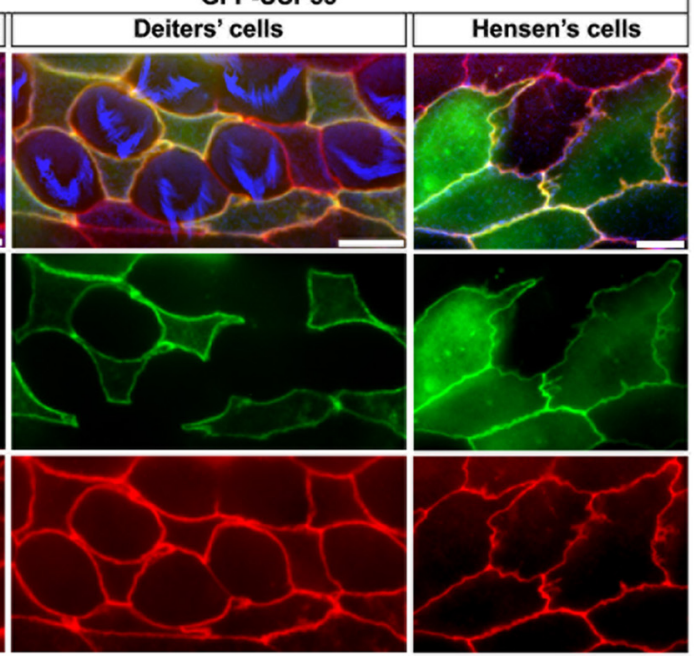

E

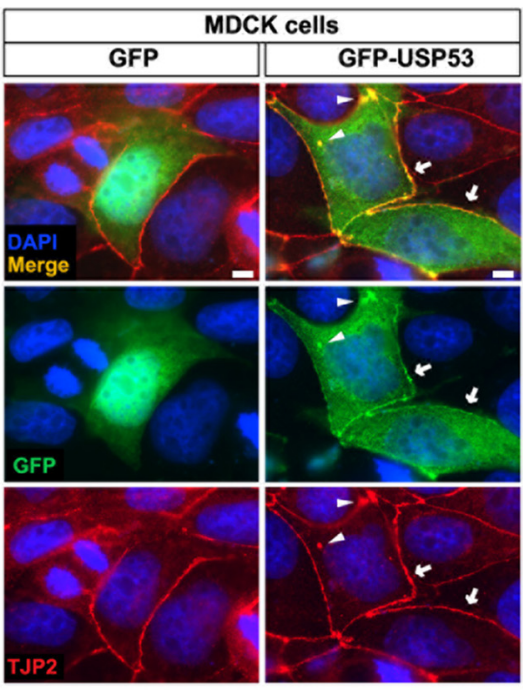

\section{D}
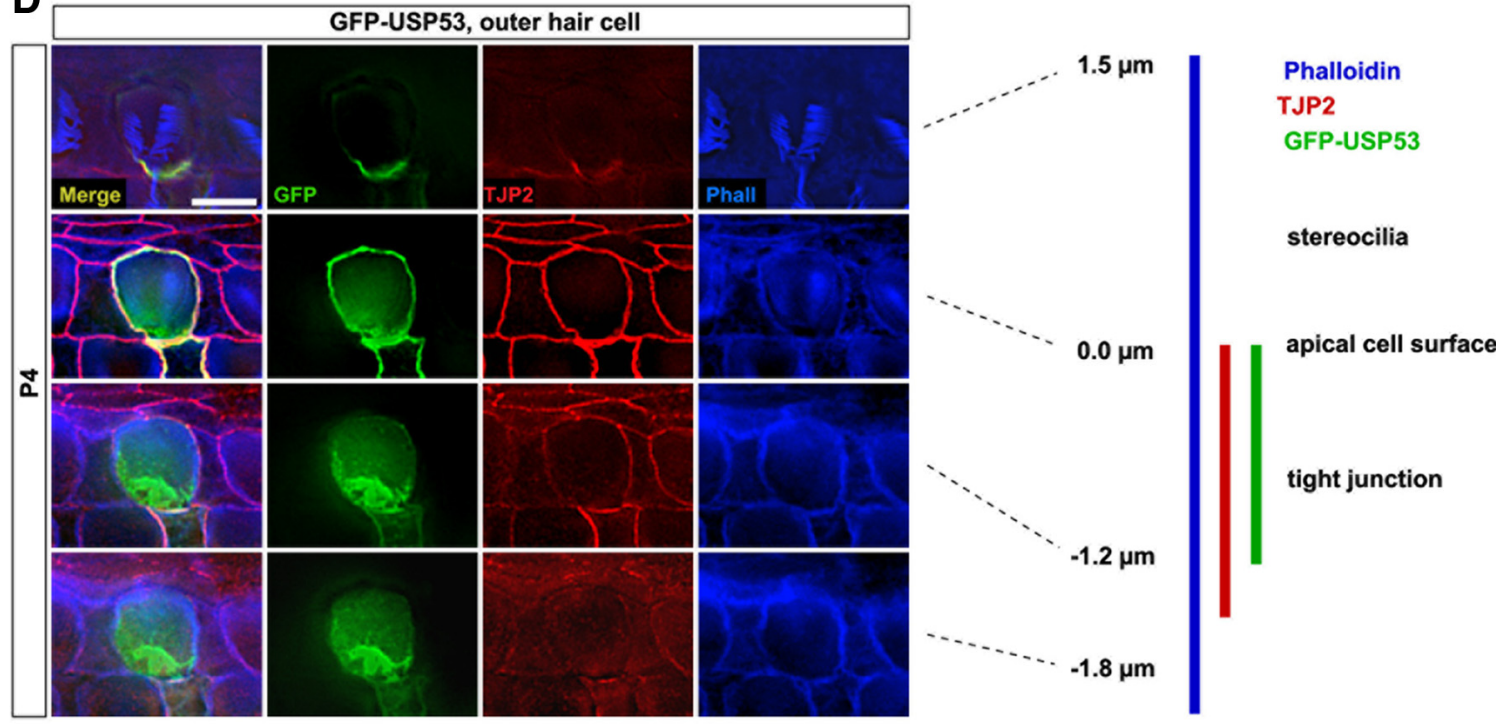

Figure 7. GFP-tagged USP53 localizes to TJs in cochlear epithelial cells and MDCK cells. $A, B$, Microscopic view of the injectoporation setup used for the transfection of hair cells and supporting cells of the organ of Corti. The position of the electrodes and the capillary delivering the plasmid $(\boldsymbol{A})$, as well as the intercellular space for plasmid injection $(\boldsymbol{B})$, are indicated. $\boldsymbol{C}$, Organs of (orti from P4 mice were injectoporated with GFP and GFP-USP53 constructs and stained with phalloidin (Phall, F-actin) and anti-TJP2 antibody after $8-12 \mathrm{~h}$ in vitro. D, Analysis of sequential $x-y$ focal planes shows the vertical distribution (z-axis) of GFP-USP53, TJP2, and F-actin in an OHC. A schematic representation of the protein distributions is shown on the right. Note the extensive colocalization of GFP-USP53 and TJP2 at the most apical part of TJs. E, MDCK cells were transfected with expression vectors for GFP and GFP-USP53 and stained with anti-TJP2 antibody (red) and DAPI (blue). GFP-USP53 and TJP2 signals colocalized at cellular junctions (arrows) and in cytoplasmic foci (arrowheads). Scale bars: C-E, $5 \mu \mathrm{m}$.

TJ properties and the EP in mambo mice

The apices of cochlear hair cells and supporting cells in the reticular lamina are joined by a band of TJs that separate the endolymph from the perilymph (Fig. 1) (Gulley and Reese,
1976). Given the junctional localization of USP53, we hypothesized that impaired TJs in the organ of Corti of mambo mice may allow endolymphatic $\mathrm{K}^{+}$to leak across the reticular lamina, thus reducing the $\mathrm{K}^{+}$gradient and EP. To explore this 
A

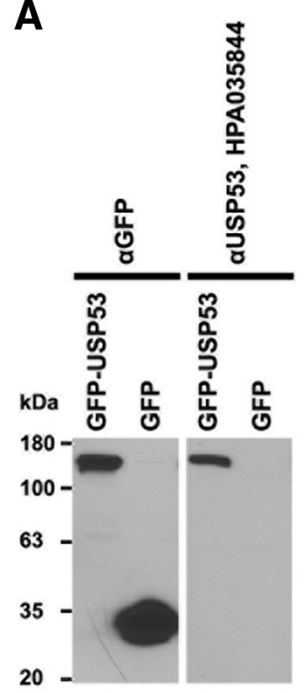

B

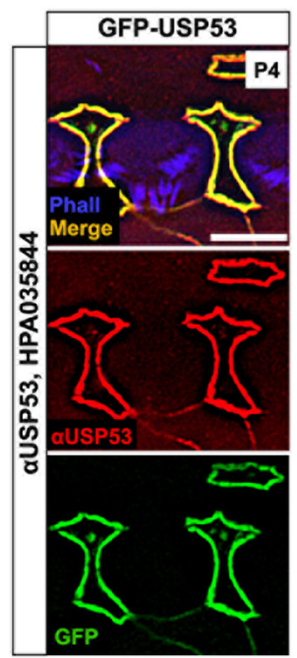

C
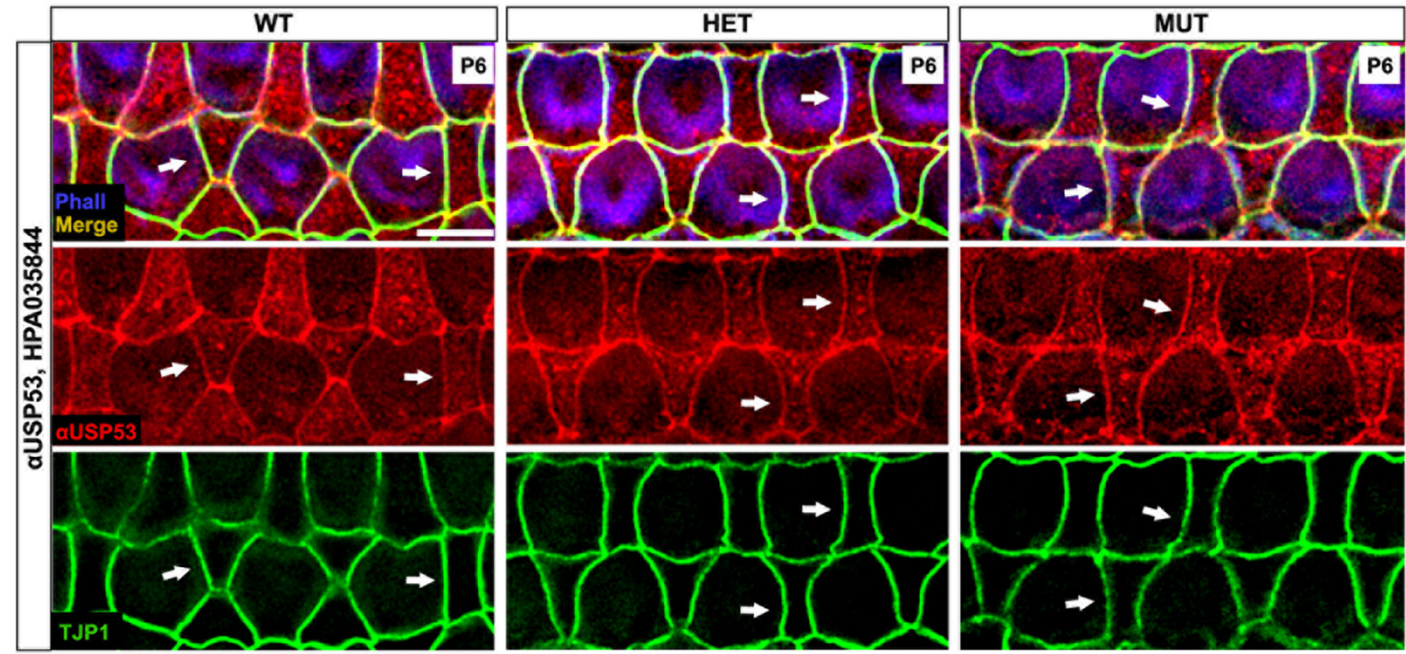

D

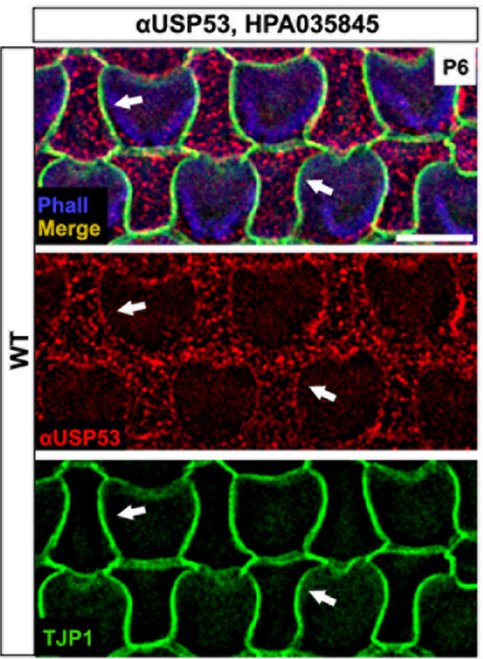

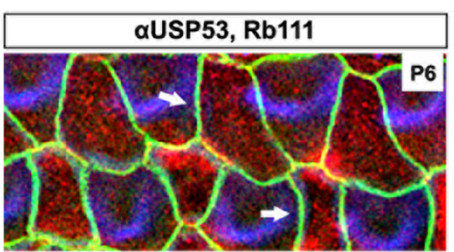
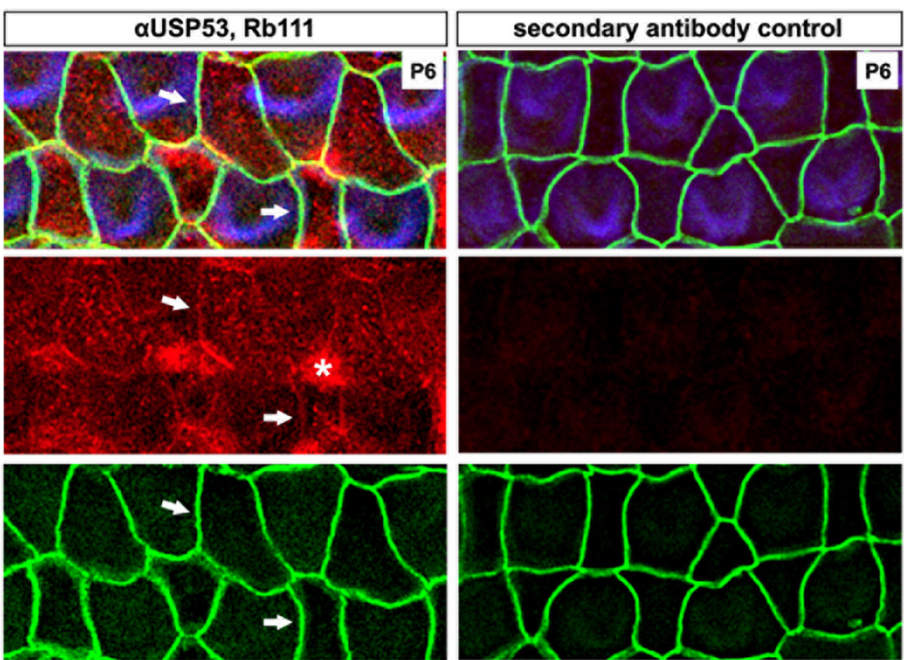

Figure 8. USP53 localizes to TJs of the reticular lamina in the organ of Corti. A, Lysates from HEK293T cells transfected with GFP-USP53 and GFP plasmids were subjected to Western blot analysis with the indicated antibodies. Anti-USP53 antibody HPA035844 (Sigma) specifically detected the GFP-USP53 fusion protein. B, Organs of Corti from P4 wild-type mice were injectoporated with GFP-USP53 and stained with anti-USP53 antibody HPA035844 (red) and phalloidin (Phall, F-actin, blue). C, Cochlear whole mounts from wild-type (WT), heterozygous (HET), and homozygous (MUT) mambo mice at P6 were stained with anti-USP53 antibody HPA035844 (red), anti-TJP1 antibody (green), and phalloidin (Phall, blue). The anti-USP53 antibody strongly labeled TJs between epithelial cells of organ of Corti in mice of all genotypes (arrows). D, Cochlear whole mounts from wild-type mice at P6 were stained with anti-USP53 antibody HPA035845 (Sigma), custom-made anti-USP53 antibody Rb111 or secondary antibody alone, used as a negative control, as well as anti-TJP1 antibody (green) and phalloidin (Phall, blue). Although these antibodies exhibit lower signal-to-noise ratios compared with HPA035844, they consistently labeled TJs between OHCs and Deiters' cells' (arrows). Nonspecific binding of Rb111 antibody to remnants of the tectorial membrane covering the cochlear epithelium led to brightly fluorescent patches (asterisk). Scale bars: $\boldsymbol{B}-\boldsymbol{D}, 5 \mu \mathrm{m}$.

possibility, we measured the EP at two time points: (1) during the development of the EP (P10); and (2) after it reached mature levels (P30) (Fig. 10A). At P10, the EP in mambo mice $(39 \pm 2 \mathrm{mV})$ was not significantly different from control mice $(36 \pm 2 \mathrm{mV})$. However, at P30, the EP increased to $>100 \mathrm{mV}$ in control mice, although it remained $\sim 17 \%$ lower in the mutants $(p<0.005$, two-tailed $t$ test $)$.

Claudin-11-deficient mice lack the EP because of impaired TJs in the basal cell layer of the stria vascularis, the structure responsible for generating the EP (Gow et al., 2004). By ISH, we did not detect Usp53 expression in the stria vascularis (Fig. $6 \mathrm{D}, \mathrm{H})$. However, given the importance of this structure for the generation and maintenance of the EP, we next examined its morphology and function. Hematoxylin-eosin staining of inner ear sections revealed no degenerative changes in the stria vascularis of 3-month-old mambo mice (Fig. $10 B, C$ ). To ana- lyze the paracellular permeability properties of the stria vascularis, a rhodamine-labeled biotin tracer was injected into the round and oval windows of heterozygous and homozygous mambo mice at P30, a time point at which a reduced EP was observed. The biotin-based tracer was not detected in the intrastrial space of homozygous mambo mice and heterozygous siblings, indicating that the tracer did not penetrate beyond the TJ barrier in the basal cell layer of the stria vacularis (Fig. $10 D-G$, arrows). Consistent with the lack of Usp53 expression in the stria vascularis, these data suggest that the paracellular permeability properties of the stria vascularis are largely unaffected in mambo mice.

Therefore, we analyzed the structure of TJs in the reticular lamina of the organ of Corti using thin-section TEM. At P10, the morphology of TJs between OHCs and Deiters' cells appeared normal at the ultrastructural level (Fig. 11A-D). Kissing points, 
A
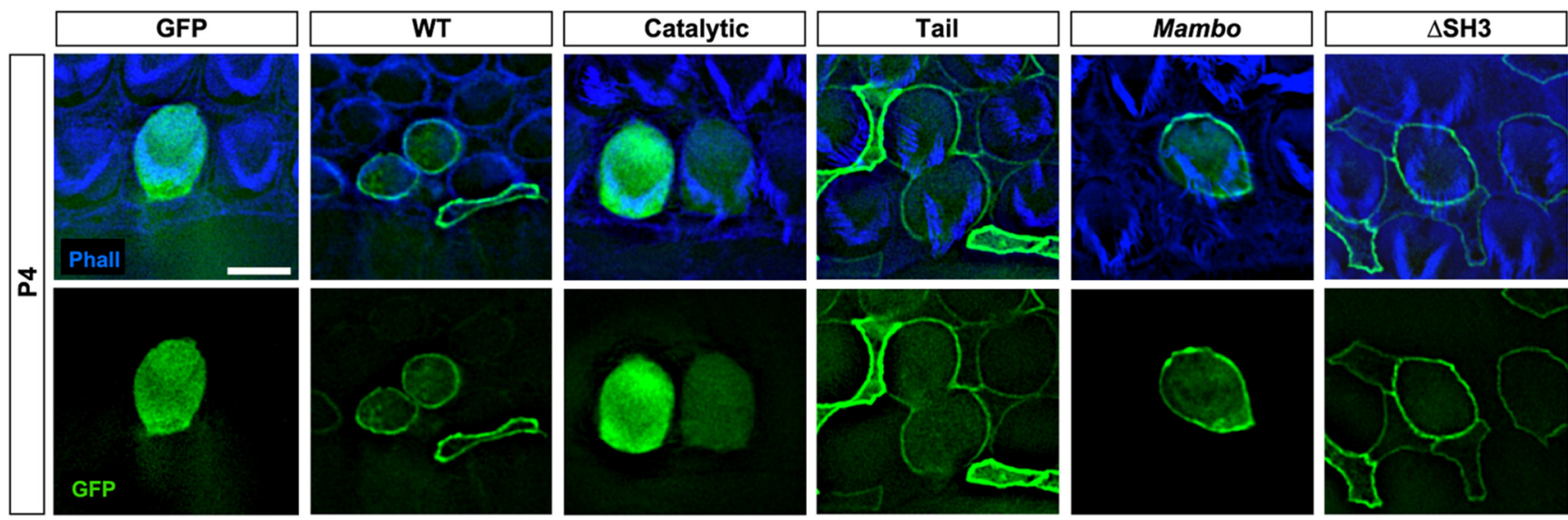

B
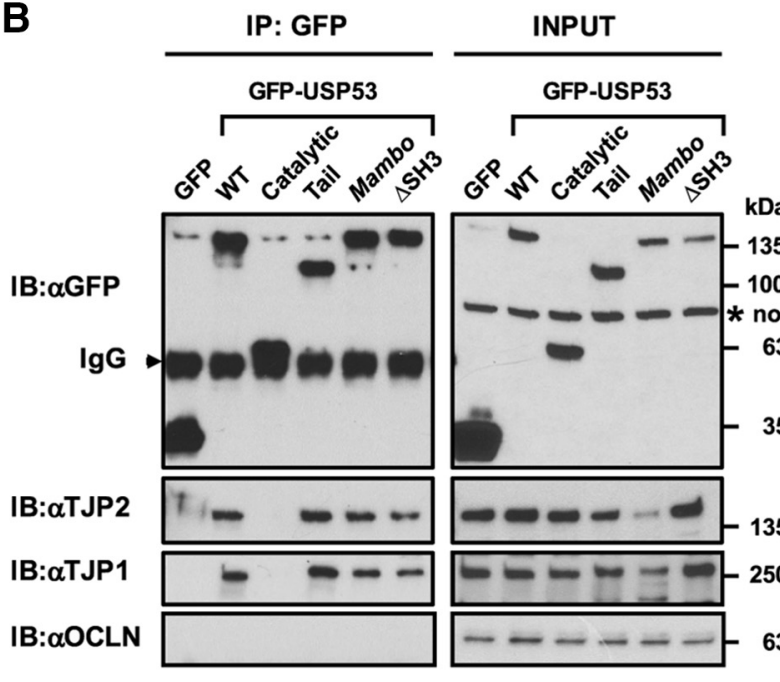

C

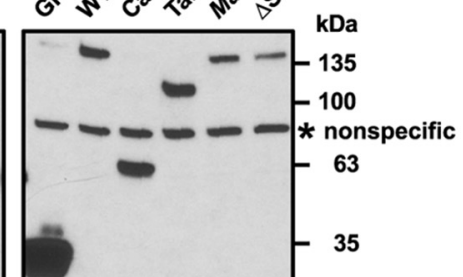

GFP

$$
\text { GFP USP }
$$

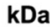

GFP-USP53 WT

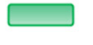

GFP-USP53 Catalytic

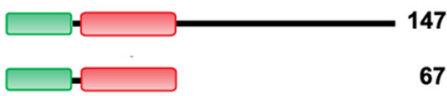

GFP-USP53 Tail

GFP-USP53 Mambo

GFP-USP53 $\Delta$ SH3

TJP2

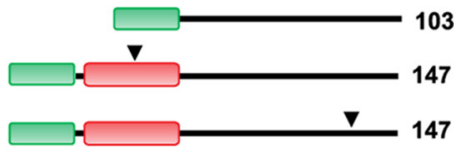

TJP1

195

OCLN

D

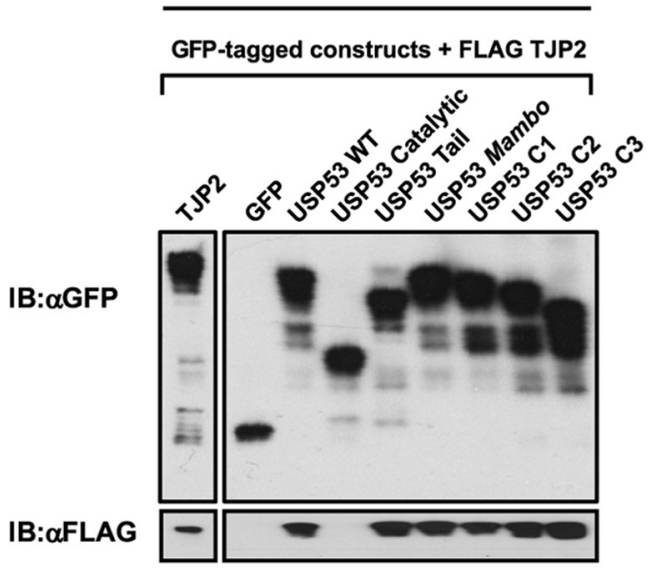

INPUT
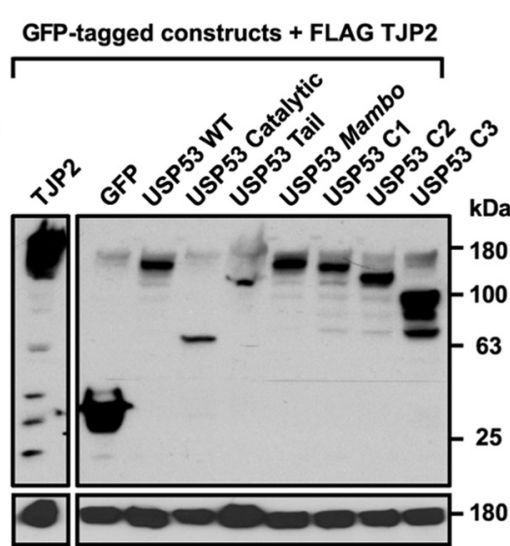

E

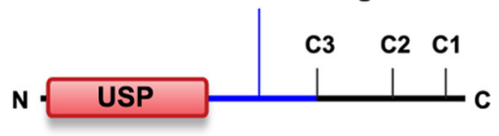

Figure 9. USP53 interacts with TJP1 and TJP2 via its C-terminal tail. A, GFP-USP53 fusion constructs, depicted schematically in C, were injectoporated into cochlear explants from P4 wild-type (WT) mice. GFP fusion proteins containing the C-terminal tail of USP53 localized to TJs. B, GFP and GFP-USP53 fusion constructs were expressed in HEK293T cells and immunoprecipitated with anti-GFP antibody (Abcam). Extracts were directly analyzed for the expression of GFP-tagged USP53 constructs using anti-GFP antibody (Sigma). An asterisk marks a nonspecific cross-reacting band at $\sim 80 \mathrm{kDa}$ used as a loading control. Native TJ proteins TJP1 and TJP2, but not occludin (OCLN), coprecipitated specifically with GFP fusion proteins that contain the C-terminal tail of USP53. IB, Immunoblot; IP, immunoprecipitation. C, Schematic diagram of the GFP-USP53 fusion proteins and TJPs used for biochemical experiments and their predicted molecular sizes. D, HEK293T cells were transfected with the constructs indicated on top of each panel. Immunoprecipitations were performed with anti-GFP antibody (Abcam) that recognizes GFP-USP53 fusion proteins followed by Western blotting with anti-FLAG antibody or anti-GFP antibody (Abcam). 2xFLAG-TJP2 coprecipitated with TJP2-GFP (TJP2 homodimerization), as well as with GFP-USP53 constructs containing a stretch of 328 aa adjacent to the catalytic domain. Neither the catalytic domain nor GFP alone precipitated 2xFLAG-TJP2. E, Schematic representation of C-terminal deletion constructs of USP53 used in $\boldsymbol{D}$. The region containing the TJP2 interaction site is highlighted in blue. Scale bar: $\boldsymbol{A}, 5 \mu \mathrm{m}$. 
A

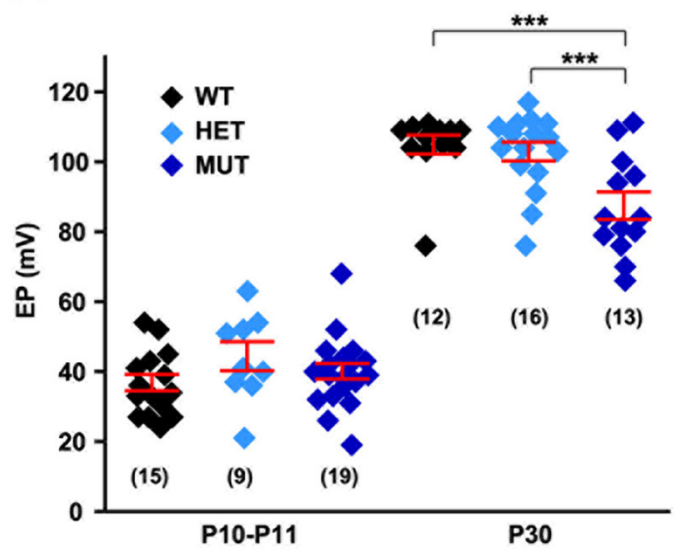

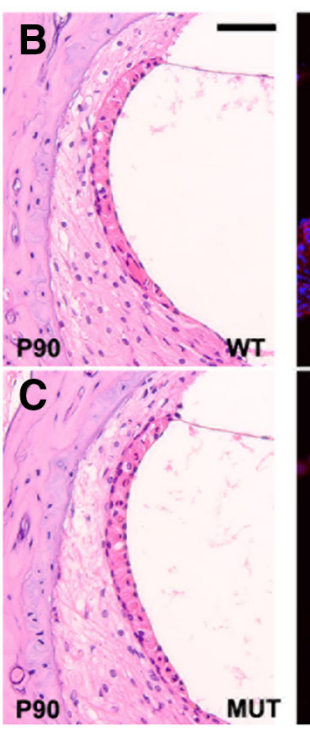
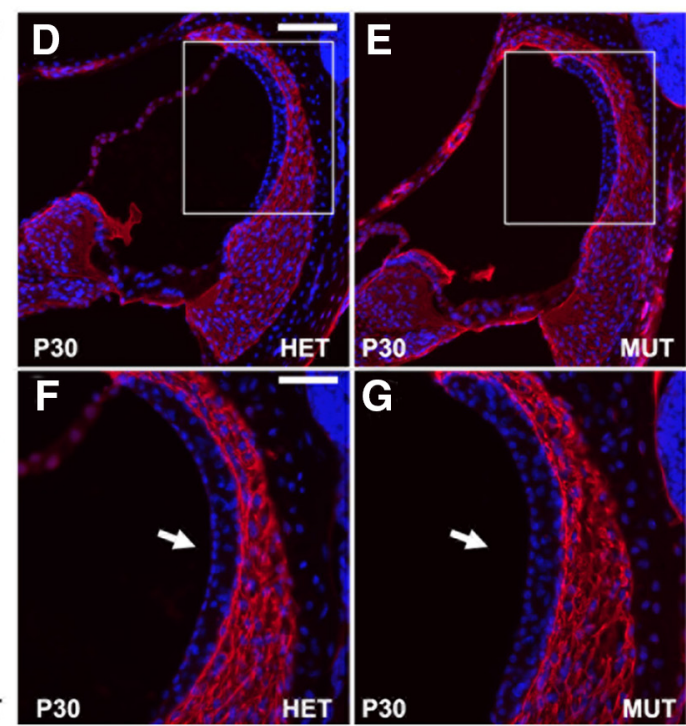
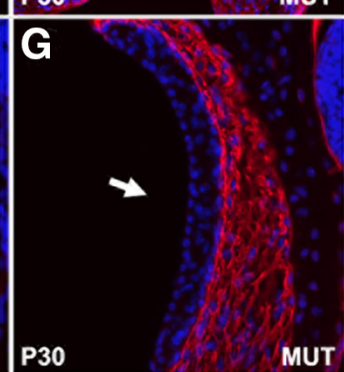

Figure 10. Reduced EP but normal barrier properties of the stria vascularis in mambo mice. $A$, EP was measured in wild-type (WT), heterozygous (HET), and homozygous (MUT) mambo mice at two time points. No significant differences between the EPs of the three groups were observed at P10. A small but significant decrease in the EP was observed in homozygous mambo mice at P30. The number of mice in each experimental group is given in parentheses. Error bars (red) represent mean $\pm \mathrm{SEM}\left({ }^{* * *} p<0.005\right.$, two-tailed $t$ test). $\boldsymbol{B}, \boldsymbol{C}$, Hematoxylin and eosin staining of inner ear sections showing the stria vascularis (SV) from wild-type and mambo mice at P90. No structural abnormalities were observed. $D-G$, Biotin tracer injections into the perilymphatic compartments of cochleae dissected from P30 heterozygous and homozygous mambo mice. The tracer (red) did not penetrate into the intrastrial space (arrows), indicating normal barrier function of TJs of the basal cells of the stria vascularis. Scale bars: (in $\boldsymbol{B}$ and $\boldsymbol{F}$ ) $\boldsymbol{B}, \boldsymbol{C}, \boldsymbol{F}, \boldsymbol{G}, 50 \mu \mathrm{m}$; (in $\boldsymbol{D}) \boldsymbol{D}, \boldsymbol{E}, 100 \mu \mathrm{m}$.

in which TJ strands between adjacent cells cause occlusion of plasma membrane, could be observed in both mambo and control mice (Fig. 11C,D, arrows). Furthermore, immunostaining of cochlear whole mounts revealed no alterations in the distribution of the TJ proteins TJP1 and TJP2 in P6 mambo mice (Fig. 11E$H$ ). These findings suggest that the apical membranes of hair cells and supporting cells are properly fused together by continuous $\mathrm{TJ}$ strands.

An impairment of TJ barrier function and increased paracellular flux of solutes, particularly $\mathrm{K}^{+}$, has been associated with $\mathrm{OHC}$ loss, although no morphological alterations in TJs have been reported (Ben-Yosef et al., 2003; Nakano et al., 2009; Kitajiri et al., 2014). To examine whether changes in the extracellular environment contribute to $\mathrm{OHC}$ degeneration in mambo mice, we assessed the degree of $\mathrm{OHC}$ loss in explant cultures of the organ of Corti in a low $\mathrm{K}^{+}$milieu $\left(4.16 \mathrm{mM} \mathrm{K}^{+}\right)$. Organs of Corti from $\mathrm{P} 7$ homozygous mambo mice and heterozygous littermates were cultured for $3 \mathrm{~d}$ ex vivo, followed by immunostaining with TJP1 and calbindin antibodies to label TJs and hair cells, respectively (Fig. 11I-L). For comparison, acutely dissected organs of Corti from 10-d-old heterozygous and homozygous mambo mice were stained with the same antibodies (Fig. $11 M-P$ ). Significant loss of OHCs was observed in vivo in homozygous mutants (Fig. $11 N, P$ ) but not in heterozygous littermates (Fig. $11 \mathrm{M}, \mathrm{O}$ ). In addition, signs of $\mathrm{OHC}$ degeneration, including fusion of stereocilia (Fig. $11 \mathrm{~N}$, arrow), submerging of $\mathrm{OHC}$ bodies under the reticular lamina, and expansion of the phalangeal processes of Deiters' cells, were evident (Fig. $11 \mathrm{~N}, P$, arrowheads). In contrast, $\mathrm{OHCs}$ in mutant organs of Corti survived when cultured ex vivo, suggesting that hair cell loss in mambo mice is triggered by changes in their microenvironment rather than intrinsic factors (Fig. 11I-L).

Heterozygous mambo mice show increased susceptibility to noise-induced hearing loss

Most epithelial cell sheets are sealed by the apical junctional complexes composed of TJs that form a permeability barrier for sol- utes and adjacent adherens junctions (AJs) that provide mechanical stability to tissues (Farquhar and Palade, 1963; Aijaz et al., 2006). The junctions between OHCs and Deiters' cells are unique in that they combine ultrastructural and molecular features of TJs and AJs and are referred to as tight adherens junctions (TAJs; Nunes et al., 2006). These combined features may allow TAJs to serve as an effective barrier to solute diffusion while withstanding the mechanical forces imposed by sound-induced vibrations and $\mathrm{OHC}$ electromotility. In support of such a dual role for TAJs, targeted deletion of the TAJ protein vezatin in $\mathrm{OHCs}$ renders mice more susceptible to noise-induced hearing loss (NIHL; Bahloul et al., 2009). Therefore, we reasoned that a similar impairment of TAJs may be present in Usp53 mutant mice.

The early-onset hearing loss in homozygous mambo mice precludes a meaningful study of noise-induced ABR threshold changes. Therefore, we challenged heterozygous animals, which do not show any hearing impairment, with an acoustic trauma. We exposed 7-week-old heterozygous mambo mice and age-matched wild-type mice to continuous broadband noise $(8-16 \mathrm{kHz})$ at $98 \mathrm{~dB}$ SPL for $2 \mathrm{~h}$ and determined ABR thresholds $2 \mathrm{~d}$ before and 2 weeks after noise exposure (Fig. $12 \mathrm{~A})$. ABR thresholds were increased in both wild-type and heterozygous mambo mice in the post-exposure group, predominantly at high frequencies (Fig. 12B). However, threshold shifts were significantly larger in heterozygous mutants $(50 \pm 6 \mathrm{~dB}$ at $28.3 \mathrm{kHz})$ than in wild-type controls $(23 \pm 6 \mathrm{~dB}$ at $28.3 \mathrm{kHz}$; Fig. 12C). This indicates that one mutant allele of Usp53 is sufficient to undermine the structural and functional integrity of the cochlear sensory epithelium, possibly by affecting the mechanical properties of TAJs.

\section{Discussion}

Over the past few years, several ubiquitin ligases have been implicated in inner ear function and cochlear homeostasis. Fbxo2, a ubiquitin ligase F-box protein, interacts with connexin 26, a gap junction protein involved in potassium recycling, and regulates its levels in the 

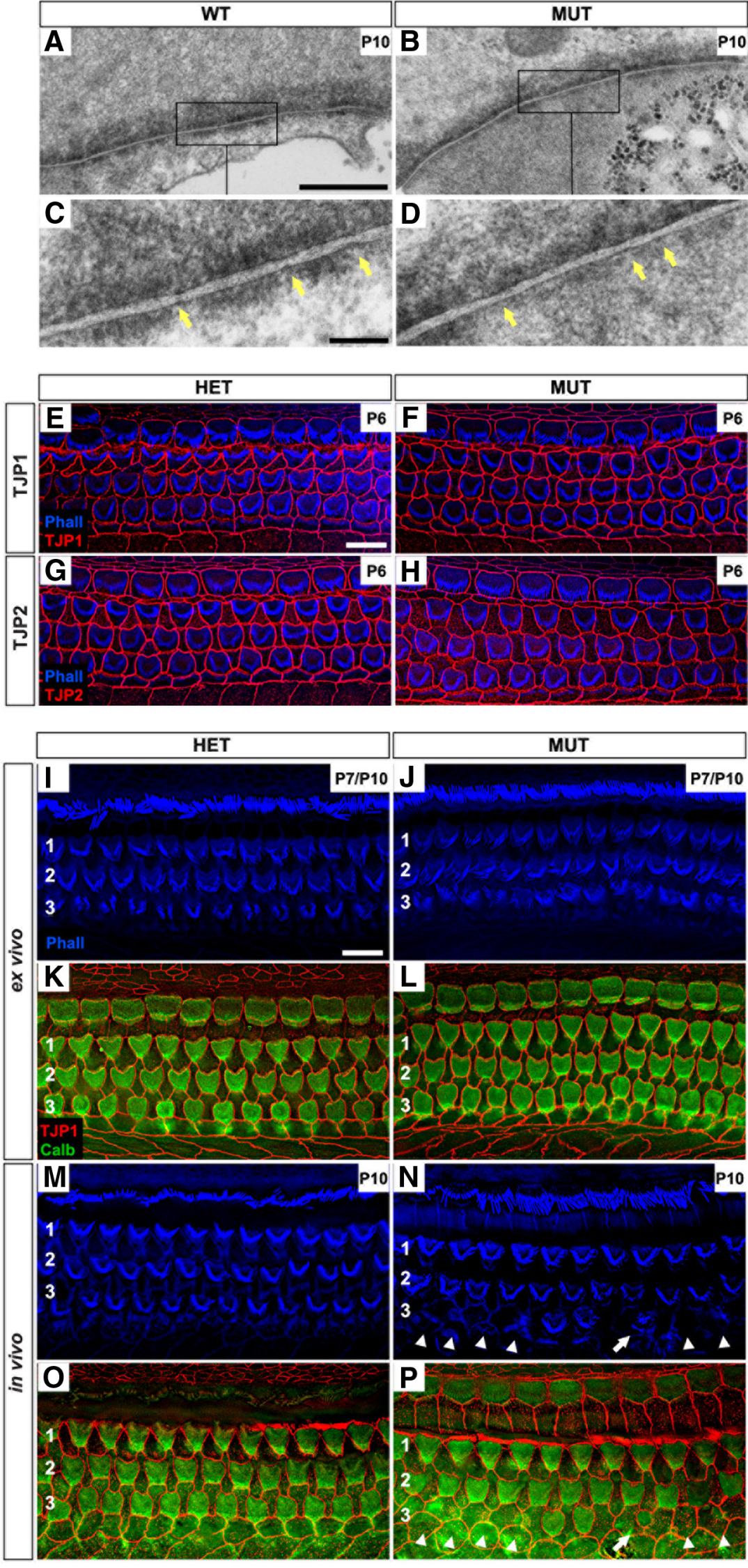

Figure 11. OHCs of mambo mice evade degeneration in organ culture. A-D TEM pictures of TJs between $0 H C s$ and Deiters' cells from wild-type (WT) and mambo (MUT) mice at P10. No abnormalities in the structure of TJs were observed. Arrows indicate sites of very close membrane appositions (kissing points). $\boldsymbol{E}-\boldsymbol{H}$, Cochlear whole mounts of P6 heterozygous (HET) and homozygous cochlea (Nelson et al., 2007). Fbxo2 null mice develop age-related hearing loss. Other E3 ubiquitin ligases, such as Nedd4-2, Rma1, and UBR1, have been implicated in the pathogenesis of syndromic deafness, including Bartter's syndrome, Pendred syndrome, and Johanson-Blizzard syndrome, respectively (Embark et al., 2004; Zenker et al., 2005; Lee et al., 2012). However, with the exception of a single study describing an association between variants in the Usp31 gene and hearing loss in dogs (Yokoyama et al., 2012), there have been no reports regarding the involvement of DUBs in auditory functions. Here we provide evidence that USP53 is a novel component of TJs in cochlear epithelial cells and affects the survival of OHCs at the onset of hearing. First, progressive hearing loss in USP53-deficient mambo mice is preceded by degenerative changes in OHCs, starting at approximately P8. Although Usp53 mRNA is distributed broadly throughout the cochlea, a feature shared with other deafness-related TJ genes (Borck et al., 2011), OHCs are selectively affected. Second, USP53 is localized to TJs in a broad range of cochlear epithelial cells, including hair cells, and binds to the TJ adaptor proteins TJP1 and TJP2. Third, OHCs evade degeneration in cochlear organotypic culture in a low $\mathrm{K}^{+}$milieu. Finally, the resistance of the organ of Corti to noiseinduced damage is compromised in Usp53 heterozygous mutant mice. We conclude that USP53 associates with TJ scaffolding proteins and is likely critical for maintaining the functional integrity of TJs, which protect $\mathrm{OHCs}$ from toxic extracellular factors and mechanical damage.

The onset of OHC defects in mambo mice coincides with the initial generation and rise of the EP. We show that mambo mice are initially capable of generating a normal EP, which is consistent with the lack of Usp53 expression in the stria vascularis. Although the EP is reduced by $20 \%$ in adult

$\leftarrow$

(MUT) mambo mice were stained with phalloidin (Phall, F-actin) and antibodies against the TJ proteins TJP1 $(\boldsymbol{E}, \boldsymbol{F})$ or TJP2 $(\boldsymbol{G}, \boldsymbol{H})$. No hair cell degeneration or abnormalities in the distribution of TJP1 and TJP2 were observed at this age. I-P, Cochlear explants from heterozygous and homozygous mambo mice were stained with phalloidin (blue) and antibodies against TJP1 (red) and calbindin (green) to visualize F-actin, TJs, and hair cells, respectively. Organs of Corti were either dissected from mice at P7 and cultured for $3 \mathrm{~d}(\boldsymbol{I}-\boldsymbol{L})$ or directly dissected at P10 before fixation and staining $(\boldsymbol{M}-\boldsymbol{P})$. Culturing organs of Corti in a low $\mathrm{K}^{+}$solution during the critical period between $\mathrm{P} 7$ and $\mathrm{P} 10$ abolished $\mathrm{OHC}$ degeneration $(\boldsymbol{J}, \boldsymbol{L})$ that is evident in acutely dissected P10 cochleae of homozygous mambo mice ( $\boldsymbol{N}, \boldsymbol{P}$, arrowheads). Scale bars: (in $\boldsymbol{A}$ ) $\boldsymbol{A}, \boldsymbol{B}, 500 \mathrm{~nm}$; (in $\boldsymbol{C}) \boldsymbol{C}, \boldsymbol{D}, 100 \mathrm{~nm}$; (in $\boldsymbol{E}$ and $\boldsymbol{I}$ ), $\boldsymbol{E}-\boldsymbol{P} 10 \mu \mathrm{m}$. 
mambo mice, the paracellular permeability of the stria vascularis is unaltered. This raises the possibility that the barrier function of epithelial cells lining the scala media is compromised. The EP decline is unlikely to reflect focal fluid leakage through lesions created in the reticular lamina by degenerating OHCs because the formation of gaps is typically prevented by concomitant expansion of the phalangeal processes of Deiters' cells (Forge, 1985; Raphael and Altschuler, 1991a,b; Raphael, 1993; Leonova and Raphael, 1997). Accordingly, our SEM analysis did not reveal any perforations of the reticular lamina in mambo mice (data not shown). On balance, the evidence suggests that subtle aberrations in TJs of the organ of Corti may lead to EP decline.

A reduction of the EP and hearing loss have also been reported in claudin-11 null mice, a phenotype that has been attributed to defective TJs in the stria vascularis (Gow et al., 2004; Kitajiri et al., 2004). Normal EPs have been reported in tricellulin, claudin-9, and claudin-14 mutant mice (Ben-Yosef et al., 2003; Nakano et al., 2009; Nayak et al., 2013), although OHC loss in these mouse models was attributed to the leakage of endolymph across the reticular lamina. It has been suggested that spatially restricted $\mathrm{TJ}$ leakage and a compensatory increase in $\mathrm{K}^{+}$secretion by the stria vascularis may account for these findings (Ben-Yosef et al., 2003; Nakano et al., 2009). The small EP decline in mambo mice could be explained by the broader expression pattern of Usp53 or a more deleterious effect of USP53 deficiency on TJ permeability. An accumulation of $\mathrm{K}^{+}$in the space of Nuel has been shown to cause prolonged depolarization and longitudinal contractions of OHCs (Zenner, 1986), which may lead to their degeneration. Our observation that OHCs of mambo mice do not degenerate ex vivo in low $\mathrm{K}^{+}$medium is consistent with this possible mechanism.

Another principal finding is the increased susceptibility of heterozygous mambo mice to NIHL. This result can perhaps be best explained by a dual mechanism, in which USP53 influences both the ion barrier function of TAJs and their resistance to mechanical stress. Although one functional allele of Usp53 is sufficient to protect the epithelium under limited noise conditions, TAJs might be weakened and more prone to noise-induced damage. To our knowledge, this is the first report of a gene encoding a TJP that promotes increased susceptibility to NIHL in heterozygous mice. Targeted homozygous deletion of another TAJ component, vezatin, in OHCs increases the susceptibility of mice to acoustic trauma. Vezatin may bridge the junctional complex to the F-actin-based cell cortex via its interaction with radixin (Bahloul et al., 2009). In analogy, USP53 binds to TJP1 and TJP2, which form a link between transmembrane TJ proteins and the cytoskeleton (Fanning et al., 1998, 2002; Wittchen et al., 1999), suggesting that a similar mechanism may render mambo mice more susceptible to noise injury. It is tempting to speculate that the increased permeability and decreased mechanical stability of TAJs may be directly related: because of the extremely low endolymphatic $\mathrm{Ca}^{2+}$ concentration (20-100 $\mu \mathrm{M}$; Ikeda and Morizono, 1988), an increase in TJ permeability may expose AJs to the low endolymphatic $\mathrm{Ca}^{2+}$ environment. This, in turn, might affect trans-interactions between
E-cadherins, which require $\mathrm{Ca}^{2+}$ concentrations as high as $1 \mathrm{~mm}$ (Pertz et al., 1999), and alter the mechanical properties of AJs.

Our data show that USP53 binds to the TJ adaptor proteins TJP1 and TJP2 but not the TJ transmembrane proteins occludin, claudin-9, or claudin-14. The association of USP53 with TJPs poses an interpretational challenge for the observed OHC phenotype in mambo mice. Aside from their role in regulating TJ assembly and stability, TJPs translocate to the nucleus to regulate gene expression (Bauer et al., 2010). Indeed, overexpression of TJP2 and altered expression of apoptosis-related genes may contribute to hearing loss in DFNA51 patients (Walsh et al., 2010). Although we cannot exclude the involvement of intrinsic cellular mechanisms in the pathophysiology of mambo mice, the mitochondrial apoptotic pathway is unlikely to underlie $\mathrm{OHC}$ death because no caspase-3 activity was detected in degenerating OHCs. Moreover, $\mathrm{OHC}$ degeneration is rescued in low $\mathrm{K}^{+}$medium, suggesting that extracellular factors trigger hair cell death. In addition, the decreased EP suggests that increased TJ permeability may allow the diffusion of $\mathrm{K}^{+}$and other extracellular factors across the reticular lamina leading to the described toxic effects of high extracellular $\mathrm{K}^{+}$on OHCs.

USP53 shows no catalytic activity in DUB inhibitor assays, which is consistent with the lack of an essential histidine residue in its active site. To our knowledge, this is the first report of an animal model of a human disorder caused by a mutation in an inactive DUB. Only 7 of the 83 members of the DUB superfamily are predicted to be inactive, including six of the USP family (Komander et al., 2009). Some inactive DUBs, such as Sad1, a yeast homolog of USP39, USPL1, and USP52, do not bind ubiquitin and have been implicated in diverse physiological processes (van Leuken et al., 2008; Schulz et al., 2012; Hadjivassiliou et al., 2014; Jonas et al., 2014). The physiological roles and ubiquitin-binding properties of USP50 and USP54 are unknown. It is possible that the ubiquitin-binding capability of USP53 has been preserved.

Three TJ proteins necessary for hearing, occludin, tricellulin, and ZO-2, are known targets of ubiquitination (Wagner et al., 2011), and ubiquitination of occludin regulates TJ permeability (Murakami et al., 2009; Rao, 2009). Furthermore, levels of TJP2 are controlled by 
the proteasome (Quiros et al., 2013) and augmented in DFNA51 patients (Walsh et al., 2010). It is tempting to speculate that binding of USP53 to TJP2 may interfere with the function of active DUBs in a dominant-negative manner by blocking the removal of ubiquitin from TJ proteins. In mambo mice, the mutant USP53 catalytic domain may fail to bind ubiquitin on target proteins and shift the dynamic balance between ubiquitination and deubiquitination, thus influencing stability or activity of TJ proteins. Alternatively, USP53 may target ubiquitin-like modifiers, such as NEDD8 or ISG15, as reported for other USPs (Gong et al., 2000; Catic et al., 2007), or it may have acquired a protein-protein interaction function, in analogy to the inactive catalytic domain of PRPF8 (Pena et al., 2007). It will be important to analyze the specificity of USP53 for ubiquitin and ubiquitin-like modifiers and identify their target TJ proteins.

Although the precise mechanism by which USP53 regulates cochlear homeostasis remains to be elucidated, the results of our study establish USP53 as a novel TJ component necessary for OHC survival and for the integrity of the auditory system. Our findings also highlight the efficiency of forward genetics approaches in identifying genes that are likely relevant to progressive hearing loss in humans.

\section{References}

Aijaz S, Balda MS, Matter K (2006) Tight junctions: molecular architecture and function. Int Rev Cytol 248:261-298. CrossRef Medline

Antonetti DA, Barber AJ, Hollinger LA, Wolpert EB, Gardner TW (1999) Vascular endothelial growth factor induces rapid phosphorylation of tight junction proteins occludin and zonula occluden 1. A potential mechanism for vascular permeability in diabetic retinopathy and tumors. J Biol Chem 274: 23463-23467. CrossRef Medline

Avvakumov GV, Walker JR, Xue S, Finerty PJ Jr, Mackenzie F, Newman EM, Dhe-Paganon S (2006) Amino-terminal dimerization, NRDP1rhodanese interaction, and inhibited catalytic domain conformation of the ubiquitin-specific protease 8 (USP8). J Biol Chem 281:38061-38070. CrossRef Medline

Bahloul A, Simmler MC, Michel V, Leibovici M, Perfettini I, Roux I, Weil D, Nouaille S, Zuo J, Zadro C, Licastro D, Gasparini P, Avan P, Hardelin JP, Petit C (2009) Vezatin, an integral membrane protein of adherens junctions, is required for the sound resilience of cochlear hair cells. EMBO Mol Med 1:125-138. CrossRef Medline

Bauer H, Zweimueller-Mayer J, Steinbacher P, Lametschwandtner A, Bauer HC (2010) The dual role of zonula occludens (ZO) proteins. J Biomed Biotechnol 2010:402593. CrossRef Medline

Ben-Yosef T, Belyantseva IA, Saunders TL, Hughes ED, Kawamoto K, Van Itallie CM, Beyer LA, Halsey K, Gardner DJ, Wilcox ER, Rasmussen J, Anderson JM, Dolan DF, Forge A, Raphael Y, Camper SA, Friedman TB (2003) Claudin 14 knockout mice, a model for autosomal recessive deafness DFNB29, are deaf due to cochlear hair cell degeneration. Hum Mol Genet 12:2049-2061. CrossRef Medline

Borck G, Ur Rehman A, Lee K, Pogoda HM, Kakar N, von Ameln S, Grillet N, Hildebrand MS, Ahmed ZM, Nürnberg G, Ansar M, Basit S, Javed Q, Morell RJ, Nasreen N, Shearer AE, Ahmad A, Kahrizi K, Shaikh RS, Ali RA, et al. (2011) Loss-of-function mutations of ILDR1 cause autosomalrecessive hearing impairment DFNB42. Am J Hum Genet 88:127-137. CrossRef Medline

Catic A, Fiebiger E, Korbel GA, Blom D, Galardy PJ, Ploegh HL (2007) Screen for ISG15-crossreactive deubiquitinases. PLoS One 2:e679. CrossRef Medline

Copeland JM, Bosdet I, Freeman JD, Guo M, Gorski SM, Hay BA (2007) echinus, required for interommatidial cell sorting and cell death in the Drosophila pupal retina, encodes a protein with homology to ubiquitin-specific proteases. BMC Dev Biol 7:82. CrossRef Medline

Embark HM, Böhmer C, Palmada M, Rajamanickam J, Wyatt AW, Wallisch S, Capasso G, Waldegger P, Seyberth HW, Waldegger S, Lang F (2004) Regulation of CLC-Ka/barttin by the ubiquitin ligase Nedd4-2 and the serum- and glucocorticoid-dependent kinases. Kidney Int 66:1918-1925. CrossRef Medline

Fanning AS, Jameson BJ, Jesaitis LA, Anderson JM (1998) The tight junction protein ZO-1 establishes a link between the transmembrane protein occludin and the actin cytoskeleton. J Biol Chem 273:29745-29753. CrossRef Medline
Fanning AS, Ma TY, Anderson JM (2002) Isolation and functional characterization of the actin binding region in the tight junction protein ZO-1. FASEB J 16:1835-1837. CrossRef Medline

Farquhar MG, Palade GE (1963) Junctional complexes in various epithelia. J Cell Biol 17:375-412. CrossRef Medline

Forge A (1985) Outer hair cell loss and supporting cell expansion following chronic gentamicin treatment. Hear Res 19:171-182. CrossRef Medline

Furuse M, Hirase T, Itoh M, Nagafuchi A, Yonemura S, Tsukita S, Tsukita S (1993) Occludin: a novel integral membrane protein localizing at tight junctions. J Cell Biol 123:1777-1788. CrossRef Medline

Gong L, Kamitani T, Millas S, Yeh ET (2000) Identification of a novel isopeptidase with dual specificity for ubiquitin- and NEDD8-conjugated proteins. J Biol Chem 275:14212-14216. CrossRef Medline

Gow A, Davies C, Southwood CM, Frolenkov G, Chrustowski M, Ng L, Yamauchi D, Marcus DC, Kachar B (2004) Deafness in Claudin 11-null mice reveals the critical contribution of basal cell tight junctions to stria vascularis function. J Neurosci 24:7051-7062. CrossRef Medline

Grillet N, Schwander M, Hildebrand MS, Sczaniecka A, Kolatkar A, Velasco J, Webster JA, Kahrizi K, Najmabadi H, Kimberling WJ, Stephan D, Bahlo M, Wiltshire T, Tarantino LM, Kuhn P, Smith RJ, Müller U (2009) Mutations in LOXHD1, an evolutionarily conserved stereociliary protein, disrupt hair cell function in mice and cause progressive hearing loss in humans. Am J Hum Genet 85:328-337. CrossRef Medline

Gulley RL, Reese TS (1976) Intercellular junctions in the reticular lamina of the organ of Corti. J Neurocytol 5:479-507. CrossRef Medline

Hadjivassiliou H, Rosenberg OS, Guthrie C (2014) The crystal structure of S. cerevisiae Sad1, a catalytically inactive deubiquitinase that is broadly required for pre-mRNA splicing. RNA 20:656-669. CrossRef Medline

Hershko A, Ciechanover A (1998) The ubiquitin system. Annu Rev Biochem 67:425-479. CrossRef Medline

Hu M, Li P, Li M, Li W, Yao T, Wu JW, Gu W, Cohen RE, Shi Y (2002) Crystal structure of a UBP-family deubiquitinating enzyme in isolation and in complex with ubiquitin aldehyde. Cell 111:1041-1054. CrossRef Medline

Ikeda K, Morizono T (1988) Calcium transport mechanism in the endolymph of the chinchilla. Hear Res 34:307-311. CrossRef Medline

Jesaitis LA, Goodenough DA (1994) Molecular characterization and tissue distribution of ZO-2, a tight junction protein homologous to ZO-1 and the Drosophila discs-large tumor suppressor protein. J Cell Biol 124: 949-961. CrossRef Medline

Jonas S, Christie M, Peter D, Bhandari D, Loh B, Huntzinger E, Weichenrieder O, Izaurralde E (2014) An asymmetric PAN3 dimer recruits a single PAN2 exonuclease to mediate mRNA deadenylation and decay. Nat Struct Mol Biol 21:599-608. CrossRef Medline

Kitajiri S, Miyamoto T, Mineharu A, Sonoda N, Furuse K, Hata M, Sasaki H, Mori Y, Kubota T, Ito J, Furuse M, Tsukita S (2004) Compartmentalization established by claudin-11-based tight junctions in stria vascularis is required for hearing through generation of endocochlear potential. J Cell Sci 117: 5087-5096. CrossRef Medline

Kitajiri S, Katsuno T, Sasaki H, Ito J, Furuse M, Tsukita S (2014) Deafness in occludin-deficient mice with dislocation of tricellulin and progressive apoptosis of the hair cells. Biol Open 3:759-766. CrossRef Medline

Komander D, Rape M (2012) The ubiquitin code. Annu Rev Biochem 81:203229. CrossRef Medline

Komander D, Clague MJ, Urbé S (2009) Breaking the chains: structure and function of the deubiquitinases. Nat Rev Mol Cell Biol 10:550-563. CrossRef Medline

Lee K, Hong TJ, Hahn JS (2012) Roles of 17-AAG-induced molecular chaperones and Rma1 E3 ubiquitin ligase in folding and degradation of Pendrin. FEBS Lett 586:2535-2541. CrossRef Medline

Leonova EV, Raphael Y (1997) Organization of cell junctions and cytoskeleton in the reticular lamina in normal and ototoxically damaged organ of Corti. Hear Res 113:14-28. CrossRef Medline

Montrasio S, Mlodzik M, Fanto M (2007) A new allele uncovers the role of echinus in the control of ommatidial rotation in the Drosophila eye. Dev Dyn 236:2936-2942. CrossRef Medline

Morozko EL, Nishio A, Ingham NJ, Chandra R, Fitzgerald T, Martelletti E, Borck G, Wilson E, Riordan GP, Wangemann P, Forge A, Steel KP, Liddle RA, Friedman TB, Belyantseva IA (2015) ILDR1 null mice, a model of human deafness DFNB42, show structural aberrations of tricellular tight junctions and degeneration of auditory hair cells. Hum Mol Genet 24:609-624. CrossRef Medline

Murakami T, Felinski EA, Antonetti DA (2009) Occludin phosphorylation and 
ubiquitination regulate tight junction trafficking and vascular endothelial growth factor-induced permeability. J Biol Chem 284:21036-21046. CrossRef Medline

Nakano Y, Kim SH, Kim HM, Sanneman JD, Zhang Y, Smith RJ, Marcus DC, Wangemann P, Nessler RA, Bánfi B (2009) A claudin-9-based ion permeability barrier is essential for hearing. PLoS Genet 5:e1000610. CrossRef Medline

Nayak G, Lee SI, Yousaf R, Edelmann SE, Trincot C, Van Itallie CM, Sinha GP, Rafeeq M, Jones SM, Belyantseva IA, Anderson JM, Forge A, Frolenkov GI, Riazuddin S (2013) Tricellulin deficiency affects tight junction architecture and cochlear hair cells. J Clin Invest 123:4036-4049. CrossRef Medline

Nelson RF, Glenn KA, Zhang Y, Wen H, Knutson T, Gouvion CM, Robinson BK, Zhou Z, Yang B, Smith RJ, Paulson HL (2007) Selective cochlear degeneration in mice lacking the F-box protein, Fbx2, a glycoprotein-specific ubiquitin ligase subunit. J Neurosci 27:5163-5171. CrossRef Medline

Nunes FD, Lopez LN, Lin HW, Davies C, Azevedo RB, Gow A, Kachar B (2006) Distinct subdomain organization and molecular composition of a tight junction with adherens junction features. J Cell Sci 119:4819-4827. CrossRef Medline

Obenauer JC, Cantley LC, Yaffe MB (2003) Scansite 2.0: Proteome-wide prediction of cell signaling interactions using short sequence motifs. Nucleic Acids Res 31:3635-3641. CrossRef Medline

Ohlemiller KK, Lett JM, Gagnon PM (2006) Cellular correlates of age-related endocochlear potential reduction in a mouse model. Hear Res 220:10-26. CrossRef Medline

Oka T, Remue E, Meerschaert K, Vanloo B, Boucherie C, Gfeller D, Bader GD, Sidhu SS, Vandekerckhove J, Gettemans J, Sudol M (2010) Functional complexes between YAP2 and ZO-2 are PDZ domain-dependent, and regulate YAP2 nuclear localization and signalling. Biochem J 432: 461-472. CrossRef Medline

Pena V, Liu S, Bujnicki JM, Lührmann R, Wahl MC (2007) Structure of a multipartite protein-protein interaction domain in splicing factor prp8 and its link to retinitis pigmentosa. Mol Cell 25:615-624. CrossRef Medline

Pertz O, Bozic D, Koch AW, Fauser C, Brancaccio A, Engel J (1999) A new crystal structure, $\mathrm{Ca}^{2+}$ dependence and mutational analysis reveal molecular details of E-cadherin homoassociation. EMBO J 18:1738-1747. CrossRef Medline

Quesada V, Díaz-Perales A, Gutiérrez-Fernández A, Garabaya C, Cal S, LópezOtín C (2004) Cloning and enzymatic analysis of 22 novel human ubiquitin-specific proteases. Biochem Biophys Res Commun 314:54-62. CrossRef Medline

Quiros M, Alarcón L, Ponce A, Giannakouros T, González-Mariscal L (2013) The intracellular fate of zonula occludens 2 is regulated by the phosphorylation of SR repeats and the phosphorylation/O-GlcNAcylation of S257. Mol Biol Cell 24:2528-2543. CrossRef Medline

Rao R (2009) Occludin phosphorylation in regulation of epithelial tight junctions. Ann N Y Acad Sci 1165:62-68. CrossRef Medline

Raphael Y (1993) Reorganization of the chick basilar papilla after acoustic trauma. J Comp Neurol 330:521-532. CrossRef Medline

Raphael Y, Altschuler RA (1991a) Scar formation after drug-induced cochlear insult. Hear Res 51:173-183. CrossRef Medline

RaphaelY, Altschuler RA (1991b) Reorganization of cytoskeletal and junctional proteins during cochlear hair cell degeneration. Cell Motil Cytoskeleton 18: 215-227. CrossRef Medline

Reijmers LG, Coats JK, Pletcher MT, Wiltshire T, Tarantino LM, Mayford M (2006) A mutant mouse with a highly specific contextual fear-conditioning deficit found in an N-ethyl-N-nitrosourea (ENU) mutagenesis screen. Learn Mem 13:143-149. CrossRef Medline

Renatus M, Parrado SG, D'Arcy A, Eidhoff U, Gerhartz B, Hassiepen U, Pierrat B, Riedl R, Vinzenz D, Worpenberg S, Kroemer M (2006) Structural basis of ubiquitin recognition by the deubiquitinating protease USP2. Structure 14: 1293-1302. CrossRef Medline

Reyes-Turcu FE, Ventii KH, Wilkinson KD (2009) Regulation and cellular roles of ubiquitin-specific deubiquitinating enzymes. Annu Rev Biochem 78:363397. CrossRef Medline

Schulz S, Chachami G, Kozaczkiewicz L, Winter U, Stankovic-Valentin N, Haas P, Hofmann K, Urlaub H, Ovaa H, Wittbrodt J, Meulmeester E, Melchior F (2012) Ubiquitin-specific protease-like 1 (USPL1) is a SUMO isopeptidase with essential, non-catalytic functions. EMBO Rep 13:930-938. CrossRef Medline

Schwander M, Sczaniecka A, Grillet N, Bailey JS, Avenarius M, Najmabadi H,
Steffy BM, Federe GC, Lagler EA, Banan R, Hice R, Grabowski-Boase L, Keithley EM, Ryan AF, Housley GD, Wiltshire T, Smith RJ, Tarantino LM, Müller U (2007) A forward genetics screen in mice identifies recessive deafness traits and reveals that pejvakin is essential for outer hair cell function. J Neurosci 27:2163-2175. CrossRef Medline

Senften M, Schwander M, Kazmierczak P, Lillo C, Shin JB, Hasson T, Géléoc GS, Gillespie PG, Williams D, Holt JR, Müller U (2006) Physical and functional interaction between protocadherin 15 and myosin VIIa in mechanosensory hair cells. J Neurosci 26:2060-2071. CrossRef Medline

Steed E, Balda MS, Matter K (2010) Dynamics and functions of tight junctions. Trends Cell Biol 20:142-149. CrossRef Medline

Tamura A, Tsukita S (2014) Paracellular barrier and channel functions of T) claudins in organizing biological systems: advances in the field of barriology revealed in knockout mice. Semin Cell Dev Biol 36:177-185. CrossRef Medline

Van Itallie CM, Gambling TM, Carson JL, Anderson JM (2005) Palmitoylation of claudins is required for efficient tight-junction localization. J Cell Sci 118: 1427-1436. CrossRef Medline

van Leuken RJ, Luna-Vargas MP, Sixma TK, Wolthuis RM, Medema RH (2008) Usp39 is essential for mitotic spindle checkpoint integrity and controls mRNA-levels of aurora B. Cell Cycle 7:2710-2719. CrossRef Medline

Wagner SA, Beli P, Weinert BT, Nielsen ML, Cox J, Mann M, Choudhary C (2011) A proteome-wide, quantitative survey of in vivo ubiquitylation sites reveals widespread regulatory roles. Mol Cell Proteomics 10:M111.013284. CrossRef Medline

Walsh T, Pierce SB, Lenz DR, Brownstein Z, Dagan-Rosenfeld O, Shahin H, Roeb W, McCarthy S, Nord AS, Gordon CR, Ben-Neriah Z, Sebat J, Kanaan M, Lee MK, Frydman M, King MC, Avraham KB (2010) Genomic duplication and overexpression of TJP2/ZO-2 leads to altered expression of apoptosis genes in progressive nonsyndromic hearing loss DFNA51. Am J Hum Genet 87:101109. CrossRef Medline

Wangemann P (2006) Supporting sensory transduction: cochlear fluid homeostasis and the endocochlear potential. J Physiol 576:11-21. CrossRef Medline

Wilcox ER, Burton QL, Naz S, Riazuddin S, Smith TN, Ploplis B, Belyantseva I, Ben-YosefT, Liburd NA, Morell RJ, Kachar B, Wu DK, Griffith AJ, Riazuddin S, Friedman TB (2001) Mutations in the gene encoding tight junction claudin-14 cause autosomal recessive deafness DFNB29. Cell 104:165-172. CrossRef Medline

Wiltshire T, Pletcher MT, Batalov S, Barnes SW, Tarantino LM, Cooke MP, Wu H, Smylie K, Santrosyan A, Copeland NG, Jenkins NA, Kalush F, Mural RJ, Glynne RJ, Kay SA, Adams MD, Fletcher CF (2003) Genome-wide singlenucleotide polymorphism analysis defines haplotype patterns in mouse. Proc Natl Acad Sci U S A 100:3380-3385. CrossRef Medline

Wittchen ES, Haskins J, Stevenson BR (1999) Protein interactions at the tight junction. Actin has multiple binding partners, and ZO-1 forms independent complexes with ZO-2 and ZO-3. J Biol Chem 274:35179-35185. CrossRef Medline

Xiong W, Wagner T, Yan L, Grillet N, Müller U (2014) Using injectoporation to deliver genes to mechanosensory hair cells. Nat Protoc 9:2438-2449. CrossRef Medline

Ye Y, Scheel H, Hofmann K, Komander D (2009) Dissection of USP catalytic domains reveals five common insertion points. Mol Biosyst 5:1797-1808. CrossRef Medline

Yokoyama JS, Lam ET, Ruhe AL, Erdman CA, Robertson KR, Webb AA, Williams DC, Chang ML, Hytönen MK, Lohi H, Hamilton SP, NeffMW (2012) Variation in genes related to cochlear biology is strongly associated with adult-onset deafness in border collies. PLoS Genet 8:e1002898. CrossRef Medline

Zenker M, Mayerle J, Lerch MM, Tagariello A, Zerres K, Durie PR, Beier M, Hülskamp G, Guzman C, Rehder H, Beemer FA, Hamel B, Vanlieferinghen P, Gershoni-Baruch R, Vieira MW, Dumic M, Auslender R, Gil-da-SilvaLopes VL, Steinlicht S, Rauh M, et al. (2005) Deficiency of UBR1, a ubiquitin ligase of the $\mathrm{N}$-end rule pathway, causes pancreatic dysfunction, malformations and mental retardation (Johanson-Blizzard syndrome). Nat Genet [Erratum (2006) 38:265] 37:1345-1350. CrossRef Medline

Zenner HP (1986) K+-induced motility and depolarization of cochlear hair cells. Direct evidence for a new pathophysiological mechanism in Meniere's disease. Arch Otorhinolaryngol 243:108-111. CrossRef Medline

Zheng QY, Johnson KR, Erway LC (1999) Assessment of hearing in 80 inbred strains of mice by ABR threshold analyses. Hear Res 130:94-107. CrossRef Medline 